Article

\title{
Effects of Memantine in a Mouse Model of Postoperative Cognitive Dysfunction
}

\author{
Ahmad Almahozi *(D, Mohamed Radhi *, Suja Alzayer and Amer Kamal \\ Physiology Department, College of Medicine and Medical Sciences, Arabian Gulf University, P.O. Box 26671, \\ Manama 1111, Bahrain; suja.alzayer@gmail.com (S.A.); amerha@agu.edu.bh (A.K.) \\ * Correspondence: a.mahozi@gmail.com (A.A.); mohamed@radhi.co (M.R.)
}

Received: 15 December 2018; Accepted: 27 February 2019; Published: 6 March 2019

\begin{abstract}
Persistent impairment in cognitive functioning postoperatively is reported by clinical and animal studies, and is labeled as postoperative cognitive dysfunction (POCD). Evidence points to an exaggerated neuroinflammatory response resulting from peripheral systemic inflammation after surgery, with subsequent cytokine-induced glutamatergic excitotoxicity and synaptic impairment. These immunological changes, among many others, are also observed in Alzheimer's disease. Memantine is an N-methyl-D-aspartate receptor (NMDAR) antagonist commonly used to treat Alzheimer's disease. Surprisingly, little research exists on the role of memantine in preventing POCD. The purpose of this study is to investigate the effects of memantine on a spectrum of cognitive functions postoperatively. Mice were divided into 3 groups and each received treatment for 4 weeks. Placebo groups received a placebo then underwent either a sham procedure or a laparotomy procedure. The memantine group received memantine hydrochloride then underwent a laparotomy procedure. Cognitive tests were performed on postoperative days (POD) 1 and 7 . Compared to sham-operated mice, placebo groups that underwent a laparotomy procedure showed impaired memory in the Morris water maze test, higher anxiety-like behavior in the open field and the elevated plus maze tests, increased depression-like behavior in the tail suspension test, and lack of preference for social novelty in the three-chamber test. On the other hand, memantine-treated mice that underwent a laparotomy procedure showed enhanced memory on POD7, improved depression-like behavior on POD1 and POD7, enhanced preference for social novelty on POD1, and no improvement in anxiety-like behavior. These findings suggest a potential protective effect of memantine in mice postoperatively on memory, depression-like behavior, and preference for social novelty.
\end{abstract}

Keywords: postoperative cognitive dysfunction; POCD; memantine; Alzehimer's; neuroinflammation; mice

\section{Introduction}

The allegations and remarks raised by family and friends of patients that underwent surgery, such as "He's never been the same since his operation" or "She's lost all interest in the family since ..." ", have led Bedford [1] to publish the first comprehensive report that describes cognitive decline after surgery in the elderly. Bedford has attributed the phenomenon mostly to anesthesia, and hypoxic intervals during anesthesia and surgery. Majority of studies since then [2-7] have focused on cardiac surgeries, especially cardiopulmonary bypass surgery, presumably due to the potential for hypoxic/hypoperfusion injury and microemboli-related ischemia during these types of surgeries. However, a large study published in 1998 [8] established long-term cognitive dysfunction (detected at 3 months after surgery) in patients undergoing non-cardiac surgery (major abdominal and orthopedic surgeries), and concluded that the occurrence of this dysfunction is not related to hypotension or hypoxemia, but to anesthesia and surgery, with advanced age being the strongest risk 
factor. Subsequent studies have also determined that this complication, now termed postoperative cognitive dysfunction (POCD), could occur after minor surgery [9], and is not related to the depth of anesthesia [10,11]. Moreover, POCD has been shown to increase the risk of developing dementia 3-5 years after surgery [12], and increase the risk of death in the first year following surgery [13].

To distinguish it from postoperative delirium, which occurs in the first few days following surgery, POCD is defined as persistent cognitive impairments (lasting for more than one week) after surgery [14]. Also, the acute and transient cognitive disturbances in delirium may involve fluctuating mental status, while POCD alterations are more subtle, and involve memory, concentration, language comprehension, and a decreased ability to process information, without changes in the levels of consciousness [15-18].

The pathophysiology underlying POCD is not yet fully understood. Accumulating evidence point to the role of peripheral systemic inflammation (due to surgical trauma) in causing exaggerated inflammatory responses in the brain [14], as shown by patient studies [19-21] and animal studies, particularly in the hippocampus [22-24]. Many of the immunological changes observed in POCD, including tau phosphorylation, cytokine-induced glutamatergic excitotoxicity, and most importantly, beta-amyloid accumulation, are similar to the changes found in Alzheimer's disease $[22,25,26]$. Therefore, both entities could be viewed as a disease continuum [15].

Currently, there is no adequate treatment or prophylaxis for POCD [14,15], and management usually revolves around identifying risks, and non-pharmacological preventive measures [27-29]. Memantine is an N-methyl-D-aspartate receptor (NMDAR) antagonist that is shown to improve cognitive function in transgenic animal models of Alzheimer's disease [30-32], and its use is widely supported by human clinical trials in treating moderate to severe Alzheimer's disease [33,34]. Surprisingly, little research exists on the role of memantine in the management of POCD. The purpose of this study is to investigate the effects of memantine on a spectrum of cognitive functions in a mouse model of POCD.

\section{Materials and Methods}

\subsection{Animals}

Male BALB/C mice $(n=60)$, aged 4-6 months were used. The animals weighed 25-36 $\mathrm{g}$ at the beginning of the experiment. All animals were housed individually in cages of $52 \mathrm{~cm}$ in length $\times$ $30 \mathrm{~cm}$ in width $\times 21 \mathrm{~cm}$ in height, with soft bedding. The animal colony was maintained at $22 \pm 2{ }^{\circ} \mathrm{C}$ and a relative humidity of $40-60 \%$, on a 12-hour light/dark cycle (lights on at 6:00 A.M). All mice were allowed ad libitum access to laboratory chow and tap water, and were given at least 1 week to acclimate to colony conditions before experimentation began.

The animals were randomly divided into three groups (Figure 1). Placebo-A (PA) group ( $\mathrm{n}=20$, from 10 different mothers) received placebo for 4 weeks, then underwent a sham procedure. Placebo-B $(\mathrm{PB})$ group $(\mathrm{n}=20$, from 10 different mothers) received placebo for 4 weeks, then underwent a laparotomy procedure. Memantine $(M)$ group $(n=20$, from 10 different mothers) received memantine hydrochloride for 4 weeks, then underwent a laparotomy procedure. For each group, half of the animals $(n=10)$ underwent behavioral testing on postoperative day 1 (POD-1), and the other half $(n=10)$ underwent behavioral testing on postoperative day 7 (POD-7). The weights ( $g$ ) of the animals were measured during the treatment period at days $7,14,21$, and 28 , and after the operations on days 1,3 , and 7 .

All experimental procedures and behavioral tests in the project (55-PI-02/16) were approved by the Research Ethics Committee, the Arabian Gulf University, Manama, Bahrain. All efforts were made to minimize the number of animals used, and the animals were handled in accordance with good animal practice. 


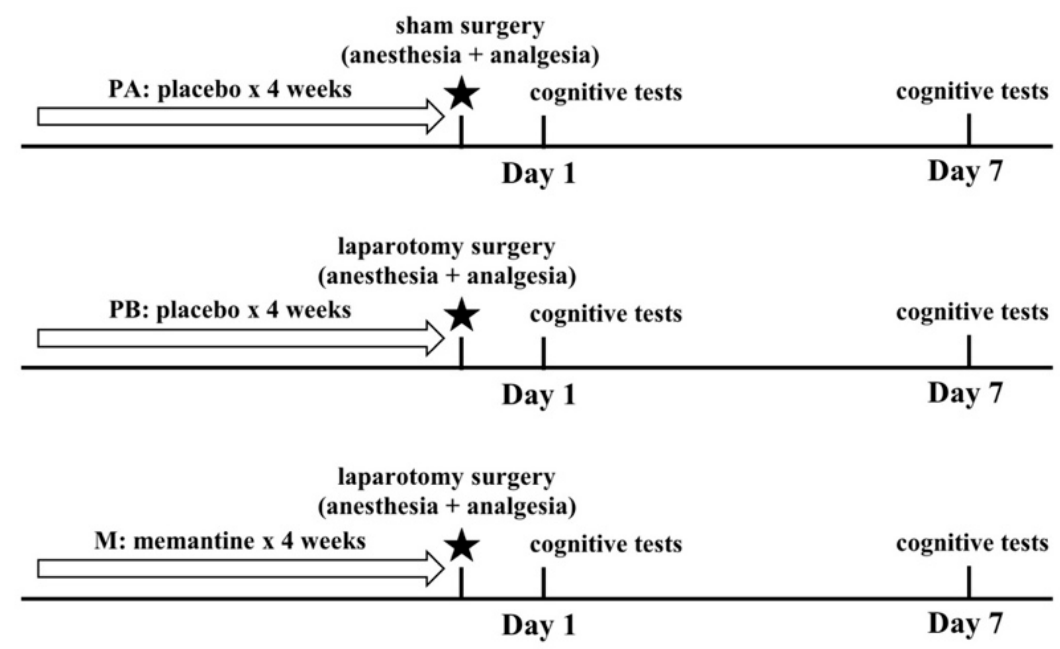

Figure 1. Experimental design. Placebo A (PA) group received placebo for 4 weeks, then underwent a sham procedure. Placebo B (PB) group received placebo for 4 weeks, then underwent a laparotomy procedure. Memantine (M) group received memantine hydrochloride for 4 weeks, then underwent a laparotomy procedure. From each group, half of the animals underwent cognitive testing on postoperative day 1 (POD1), and the other half underwent cognitive testing on postoperative day 7 (POD7).

\subsection{Treatment}

For the memantine group (M), memantine hydrochloride (Lundbeck A/S, Denmark) was administered daily for 4 weeks, as a solution in physiological saline via oral gavage, at a therapeutic dose of $30 \mathrm{mg} / \mathrm{kg} /$ day. A steady-state plasma drug level of memantine of around $1 \mu \mathrm{mol} / \mathrm{L}$ in mice is considered therapeutic [35-37], and a dose of $30 \mathrm{mg} / \mathrm{kg} /$ day is shown to be sufficient to reach that level [30]. To control for the effects of stress, placebo groups (PA and PB) received physiological saline ( $0.9 \%$ sodium chloride, Argyle, Covidien, USA) via oral gavage for 4 weeks.

\subsection{Surgical Procedure}

Laparotomies and sham surgeries were performed using aseptic procedures under general anesthesia with intraperitoneal injections of ketamine (Hikma Pharmaceuticals PLC, UK) at a dose of $1.0 \mathrm{mg} / 10 \mathrm{~g}$ body weight and xylazine (Bomac Laboratroies Ltd., New Zealand) at a dose of $0.1 \mathrm{mg} / 10 \mathrm{~g}$ body weight, following a previously described method [38].

After the induction of anesthesia, the abdominal region was shaved and thoroughly cleaned with $70 \%$ ethanol (Green Cross, Philippines) and surgical scrub (Povidone-iodine 10\%, Purdue Products L.P., Stamford, CT). Approximately $0.5 \mathrm{~cm}$ below the left rib in the left upper abdominal quadrant, a $1.5 \mathrm{~cm}$ vertical incision was made, penetrating the skin and the peritoneal cavity. A sterile probe was inserted into the opening and manipulated the viscera and musculature for $1 \mathrm{~min}$. Sterile dissolvable sutures (Vicryl 3-0, $70 \mathrm{~cm}$; Ethicon) were used to suture the abdominal muscles. The skin was closed with silk thread sutures. To reduce the risk of infection, the wound was dressed with Polysporin (Pfizer). Sham-operated mice (PA group) were anesthetized, and the abdominal area was shaved and cleaned as described above. They remained on ketamine and xylazine for the same amount of time as their surgical counterpart (about $10 \mathrm{~min}$ ). Upon recovery from anesthesia, all animals received buprenorphine (Napp Pharmaceuticals Ltd., Cambridge, UK) at a dose of $1.0 \mathrm{mg} / 10 \mathrm{~g}$ body weight subcutaneously for analgesia. All procedures were performed by one person to limit variability. In the postoperative period, surgical wounds were inspected daily for wound dehiscence or discharge. 


\subsection{The Tests}

Behavioral tests were conducted between 6:00 A.M and 6:00 P.M. All sessions were videotaped, and were conducted and scored blindly. To eliminate possible inter-observer variability, each parameter was scored by one observer for all mice.

\subsubsection{The Morris Water Maze}

Each animal underwent 5 training trials per day for the first day in the Morris water maze, followed by 3 trials in the second day, and a final probe trial on the third day, as previously described [39,40].

The maze consisted of a large circular swimming pool, measuring $140 \mathrm{~cm}$ in diameter and $50 \mathrm{~cm}$ in height, filled to a depth of $30 \mathrm{~cm}$, and the water was maintained warm at $24^{\circ} \mathrm{C}$. The pool was placed in a darkened room that is illuminated by sparse red light, with surrounding extra-maze visual cues. Two imaginary diagonal lines divided the pool into 4 equal quadrants. Mice were given acquisition trials to learn the position of a hidden platform (diameter $12 \mathrm{~cm}$ ), submerged $2 \mathrm{~cm}$ below the water surface, in the center of one quadrant. Performance in the trials was averaged to yield one single data point per mice per day. On each trial, the mice were released into the water facing the wall of the pool from one of four randomly assigned positions on the perimeter of the pool $(\mathrm{N}, \mathrm{W}, \mathrm{S}, \mathrm{E})$, and were allowed a maximum of 120 seconds per session to find the hidden platform. They were allowed to remain on the platform for 30 seconds in between sessions. If an animal failed to find the platform within the allowed time, an experimenter would gently guide the animal to the platform.

The position and movement of the animals in the pool were recorded and analyzed using the ANY-maze video-tracking system (Stoelting Co, Wood Dale, IL, USA). Outcome measures were time spent to reach the platform (latency time), distance swum to reach the platform, and speed of swimming. On the third day, a final probe trial was conducted in which the platform was removed and each animal was allowed to swim for 60 seconds. The time spent in the zone that previously contained the platform was analyzed, and the selective search strategy was indicated if animals performed significantly above chance (25\%).

\subsubsection{The Open Field Test}

Locomotor function and anxiety were assessed using the open field test, as described previously [41]. A square wooden open field $(44 \times 44 \times 32 \mathrm{~cm})$ was subdivided into 16 even squares with thin white stripes. Each mouse was placed in next to the wall of the arena, facing away from the experimenter. Behavior was recorded for $10 \mathrm{~min}$.

Outcome measures were distance traveled (indicated by number of line crossings), frequency of central zone entry, and time spent in the central zone (the central four squares). Distance traveled reflected the general motor function. Time spent in the central zone and frequency of central area entry were measures of anxiety. At the end of each trial, the arena was cleaned using $70 \%$ ethanol to prevent olfactory cue bias.

\subsubsection{The Elevated Plus-Maze Test}

Anxiety-like behavior was assessed using the elevated plus-maze test, as described previously [42]. The apparatus comprised of four arms; two open, unprotected arms $(25 \times 5 \mathrm{~cm})$ surrounded by small walls ( $3 \mathrm{~mm}$ high) to prevent the animals from falling, and two enclosed, protected arms $(25 \times 5 \mathrm{~cm})$ surrounded by high walls ( $15 \mathrm{~cm}$ high). All arms were elevated $55 \mathrm{~cm}$ above the floor. Arms of the same type were located opposite to each other, with an empty square $(5 \times 5 \mathrm{~cm})$ in the center of the maze. The test started by individually placing each mouse in the central square facing one of the closed arms, and allowing it to freely explore the apparatus for $10 \mathrm{~min}$.

Measures recorded were the number of entries into an arm, and the time spent in open and closed arms. Percentage of entries into open arms, time spent in open arms, and total number of entries were analyzed. Entry into an arm was defined as all four limbs in an arm. Anxiety-like behavior was 
indicated by decreased number of entries into the open arms, and spending less time in the open arms. Total number of entries into open and closed arms was a measure of general activity. After each session, the apparatus was cleaned thoroughly with $70 \%$ ethanol.

\subsubsection{The Tail-Suspension Test}

The tail-suspension test was used to assess depression-related behavior, as described previously [43]. A rectangular box (walls made of Plexiglas, measuring $45 \times 24 \times 24 \mathrm{~cm}$ ) was used. On top of the box, a suspension bar (made of aluminum, measuring $1 \times 1 \times 55 \mathrm{~cm}$ ) was placed and used to suspend the tail of the mouse. Each mouse was suspended separately in the middle of the box, using an adhesive black tape applied to the end of the tail (with 2-3 millimeters remaining outside of the tape), and the free end of the tape was attached to the middle of the suspension bar. The box was sufficiently sized so the animal could not make contact with the walls. The approximate distance between the mouse's nose and the apparatus floor was 10-15 cm. Every session lasted for $6 \mathrm{~min}$, and was recorded using a video camera placed on a tripod in front of the box. At the end of every session, the adhesive tape was gently removed from the tail, and the suspension box was thoroughly wiped with $70 \%$ ethanol.

The time that each mouse spent as immobile was measured. Mobility included escape-related behaviors, such as trying to reach the walls of the apparatus and the suspension bar, strong shaking of the body, and movement of the limbs akin to running. Small movements that were confined to the front legs but without the involvement of the hind legs were not counted as mobility. Swinging movements resulting from previous bouts of mobility also were not counted as mobility. Lack of escape-related behavior is considered immobility, which is indicative of depression-like behavior.

\subsubsection{The Three-Chamber Test}

The three-chamber test [44] was used to assess sociability and preference for social novelty. The apparatus consisted of a rectangular box (walls made of Plexiglas) with removable partitions separating the box into three chambers. Each chamber was $20 \times 40 \times 22 \mathrm{~cm}$. The dividing walls have small square openings $(5 \mathrm{~cm} \times 3 \mathrm{~cm})$ which allow the mouse to move freely from one chamber to another. Each side chamber contained a circular metal wire cage, large enough to hold a single mouse (11 cm high, $9 \mathrm{~cm}$ diameter, and bars spaced $0.5 \mathrm{~cm}$ apart). The test consisted of two sessions: session 1 (testing sociability), and session 2 (testing preference for social novelty). Animals used were subject mice (PA, PB, and M groups), and naïve "stranger" mice (of the same age, gender, and background as the subject mice) that had no prior contact with the subject mice. To allow adaptation, the subject mouse was placed in the center of the middle chamber and left to habituate for $5 \mathrm{~min}$.

In session 1, an unfamiliar mouse (stranger 1) was placed inside the wire cage that was located in one of the side chambers. The placement of stranger 1 in the left or right side of the chamber was systematically altered between trials. The partitioning walls between the chambers were removed to allow free access for the subject mouse to explore each of the three chambers. Session 1 was recorded and continued for $10 \mathrm{~min}$. The parameters assessed were time spent in each chamber and the total number of chamber entries.

After the end of session 1, session 2 started immediately with the placement of a second unfamiliar mouse (stranger 2) inside the other wire cage that was placed in the center of the opposite side chamber (which was previously empty during session 1). The subject mouse had the freedom to access all three chambers. The duration for session 2 was $10 \mathrm{~min}$, and the same parameters were assessed as in session 1 . After each session, all chambers were cleaned with $70 \%$ ethanol to prevent olfactory cue bias.

Normal sociability/social motivation (tested in session 1) was indicated by spending more time in the chamber containing stranger 1 compared to the chamber with empty cage. Intact social memory and predilection for novel experiences (tested in session 2) were indicated by spending more time in the chamber containing the newly encountered mouse (stranger 2) compared to the chamber containing the first, already-investigated mouse (stranger 1$)$. 


\subsection{Data Analysis}

Statistical analyses were performed using SPSS package (version PASW Statistic 18.0.3) and Microsoft Excel (version 15.41). All data are represented as mean \pm standard error of the mean (SEM). Differences in the performance between and within groups were assessed using a one-way analysis of variance (ANOVA), followed by paired or unpaired post-hoc $\mathrm{t}$-tests. Statistical significance was set at a $p$ value of less than 0.05 .

\section{Results}

\subsection{Significant Weight Loss in Groups that Underwent Laparotomy Procedure Compared to Sham-Operated Mice}

Weight changes were recorded for all animals (Table 1 and Figure 2). No significant differences were found between the groups during the treatment period (days 1-28). On postoperative days 1 and 3 (days 29 and 31 of the experiment, respectively), the PA group had higher weights compared to $\mathrm{PB}$ and $\mathrm{M}$ groups. On postoperative day 7, the final day of the experiment (day 35), there were no significant differences between the groups. Additionally, surgical wounds were inspected daily in the postoperative period. No wound dehiscence or discharge were found in any of the animals.

Table 1. Body weight (g). Data shown as mean \pm standard error of the mean (SEM), $p$ values given for t-tests.

\begin{tabular}{cccc}
\hline Day $^{\mathbf{1}}$ & PA $(\mathbf{n}=\mathbf{2 0})$ & PB $(\mathbf{n}=\mathbf{2 0})$ & $\mathbf{M}(\mathbf{n}=\mathbf{2 0})$ \\
\hline 1 & $29.5 \pm 0.9$ & $30.1 \pm 0.8$ & $29.9 \pm 0.9$ \\
7 & $30 \pm 0.4$ & $31 \pm 0.9$ & $30 \pm 0.9$ \\
14 & $28.3 \pm 0.8$ & $27.9 \pm 0.9$ & $29 \pm 1$ \\
21 & $31.2 \pm 0.5$ & $29.9 \pm 1.1$ & $31.3 \pm 0.8$ \\
28 & $27.9 \pm 0.9$ & $29 \pm 1.1$ & $28.9 \pm 0.9$ \\
29 (POD1) & $30.1 \pm 0.9$ & $27 \pm 1.1^{*}$ & $26.2 \pm 0.9^{* *}$ \\
31 (POD3) & $31 \pm 1$ & $26 \pm 0.9^{* *}$ & $26.6 \pm 0.8^{* *}$ \\
35 (POD7) & $29.5 \pm 1.1$ & $31 \pm 1$ & $30.1 \pm 1.1$ \\
\hline
\end{tabular}

${ }^{1}$ Days 1-28: treatment period. POD: postoperative day ${ }^{*} p<0.05$ as compared to PA. ${ }^{* *} p<0.01$ as compared to PA.

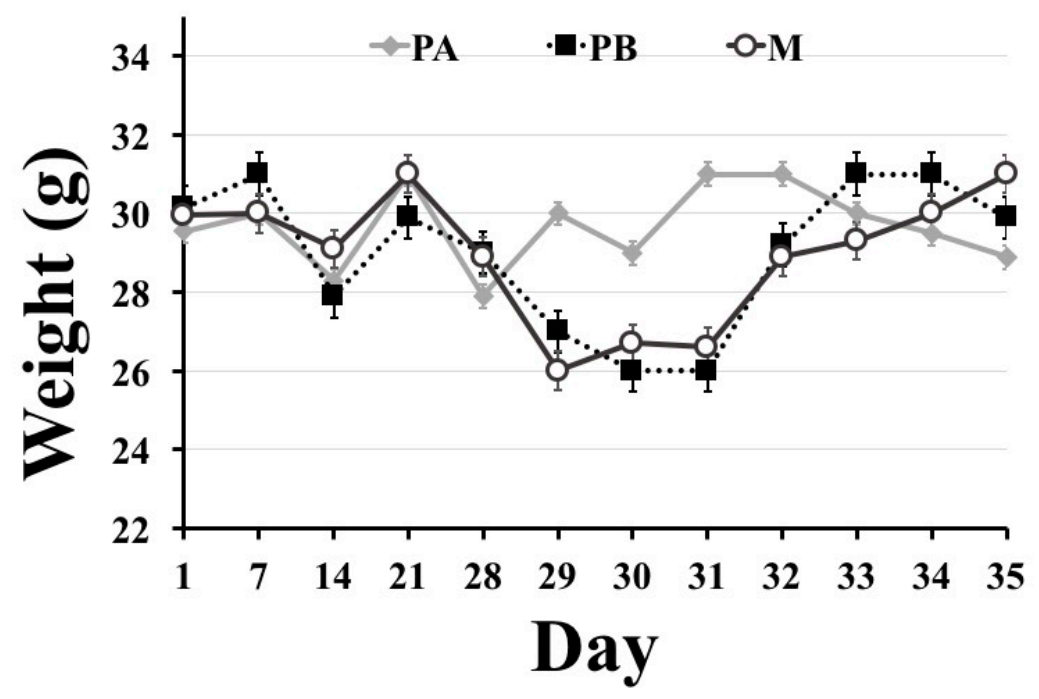

Figure 2. Changes in body weight (g). On postoperative days 1 and 3 (days 29 and 31 of the experiment), mice that underwent surgery (PB and M) had lower weights compared to sham-operated mice (PA). On postoperative day 7 (day 35 of the experiment), all groups had similar weights. Data shown as mean \pm SEM. 
3.2. Impaired Memory Following Surgery, with Improved Performance in Memantine Group on Postoperative Day 7

Memory and learning were assessed using the Morris water maze. On postoperative day 1 (Table 2), sham-operated mice (PA-POD1) spent less time to reach the platform (Figure 3A), and more time in the disc zone (Figure 3B) compared to mice that underwent surgery (PB-POD1 and M-POD1). PB-POD1 travelled more distance to reach the platform compared to the other two groups (Figure 3C), with no significant differences in the speed of swimming (Figure 3D).

Table 2. The Morris water maze. Data shown as mean $\pm \mathrm{SEM}, p$ values given for t-tests.

\begin{tabular}{ccccc}
\hline Group $^{\mathbf{1}}$ & Latency (s) & Time in Disc Zone (\%) & Distance Swum (dm) & Speed of Swimming (m/s) \\
\hline PA-POD1 & $42.2 \pm 6.3$ & $30.4 \pm 1.2$ & $8.6 \pm 2$ & $0.22 \pm 0.02$ \\
PB-POD1 & $61.2 \pm 7.7^{* *}$ & $21.6 \pm 1.4^{* *}$ & $14.7 \pm 2.6^{*}$ & $0.23 \pm 0.01$ \\
M-POD1 & $54.4 \pm 4.4^{* *}$ & $22.7 \pm 4^{*}$ & $8.3 \pm 1$ & $0.25 \pm 0.02$ \\
\hline PA-POD7 & $45 \pm 9$ & $35.4 \pm 2.5$ & $6.2 \pm 1$ & $0.27 \pm 0.02$ \\
PB-POD7 & $67.7 \pm 4.6^{\dagger}$ & $24.6 \pm 3.2^{++}$ & $10.5 \pm 1.1^{+\dagger}$ & $0.26 \pm 0.02$ \\
M-POD7 & $47.3 \pm 4.7^{*}$ & $35.3 \pm 4$ & $5.2 \pm 0.6$ & $0.25 \pm 0.02$ \\
\hline
\end{tabular}

${ }^{1}$ Each group $(\mathrm{n}=10) .{ }^{*} p<0.05$ as compared to PA-POD1. ${ }^{* *} p<0.01$ as compared to PA-POD1. ${ }^{\dagger} p<0.05$ as compared to PA-POD7. ${ }^{+t} p<0.01$ as compared to PA-POD7

A

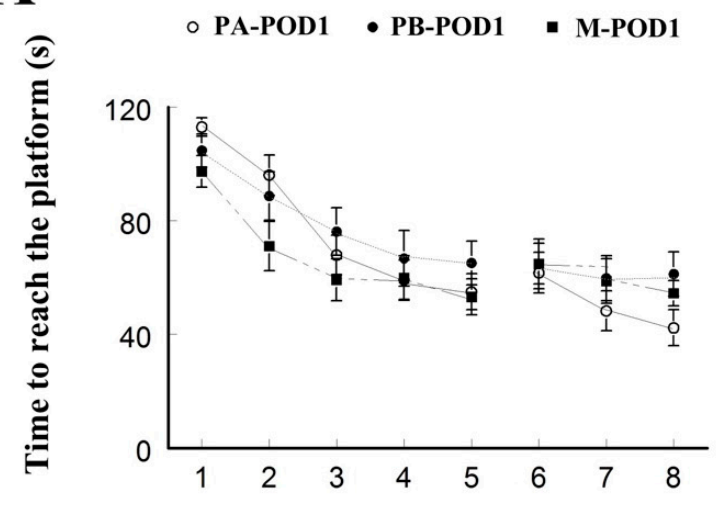

C

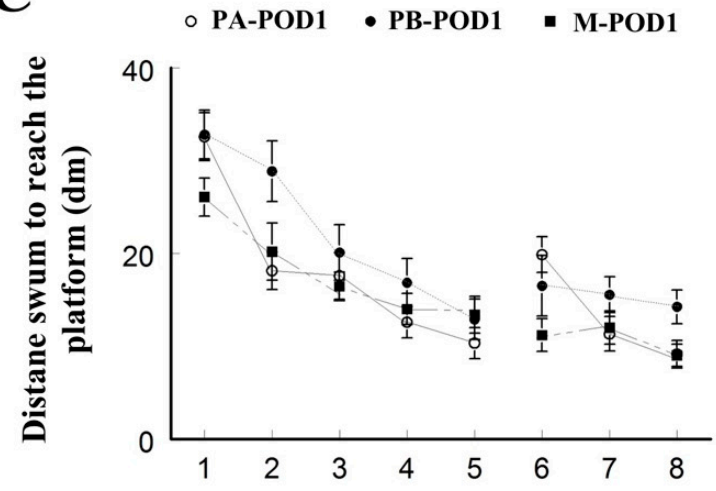

B

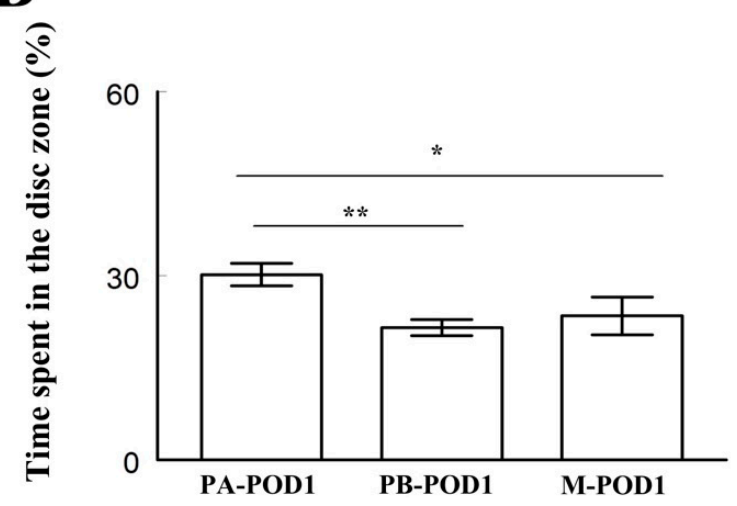

D

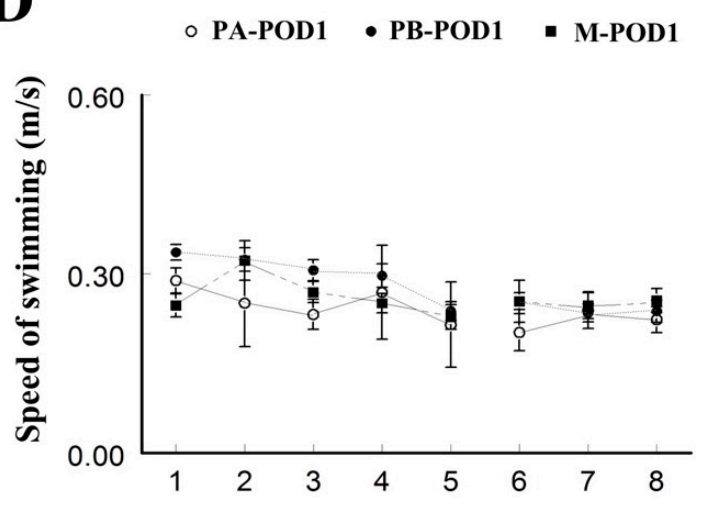

Figure 3. Morris water maze was used to assess for memory (postoperative day 1). (a) Time to reach the platform (latency); (b) time spent in the disc zone; (c) distance swum to reach the platform; and (d) speed of swimming. Sham-operated mice (PA-POD1) spent less time to reach the platform, and more time in the disc zone compared to mice that underwent surgery (PB-POD1 and M-POD1). PB-POD1 travelled more distance to reach the platform compared to the other two groups, with no significant differences in the speed of swimming between the three groups. Data shown as mean \pm SEM. ${ }^{*} p<0.05,{ }^{* *} p<0.01$. 
On postoperative day 7 (Table 2), sham-operated mice (PA-POD7) and memantine-treated mice (M-POD7) spent less time to reach the platform (Figure 4A), more time in the disc zone (Figure 4B), and travelled less distance (Figure $4 \mathrm{C}$ ) compared to operated-mice that received placebo (PB-POD1). No significant differences were found in the speed of swimming (Figure 4D).

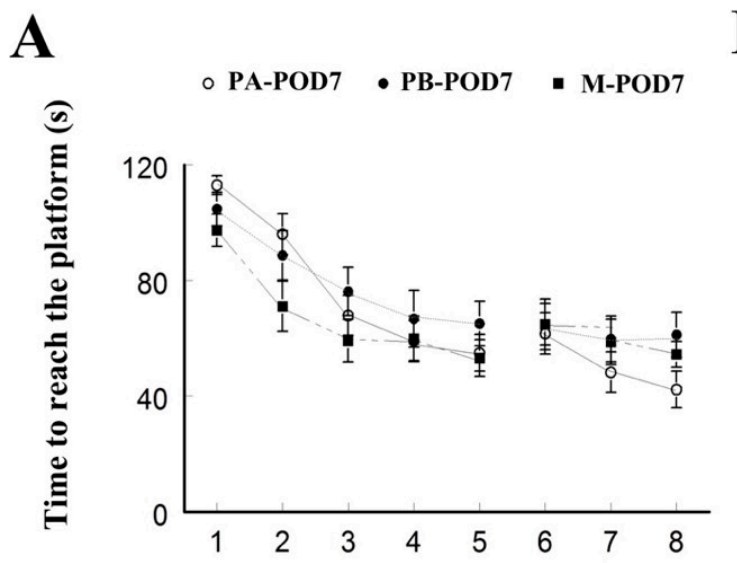

B
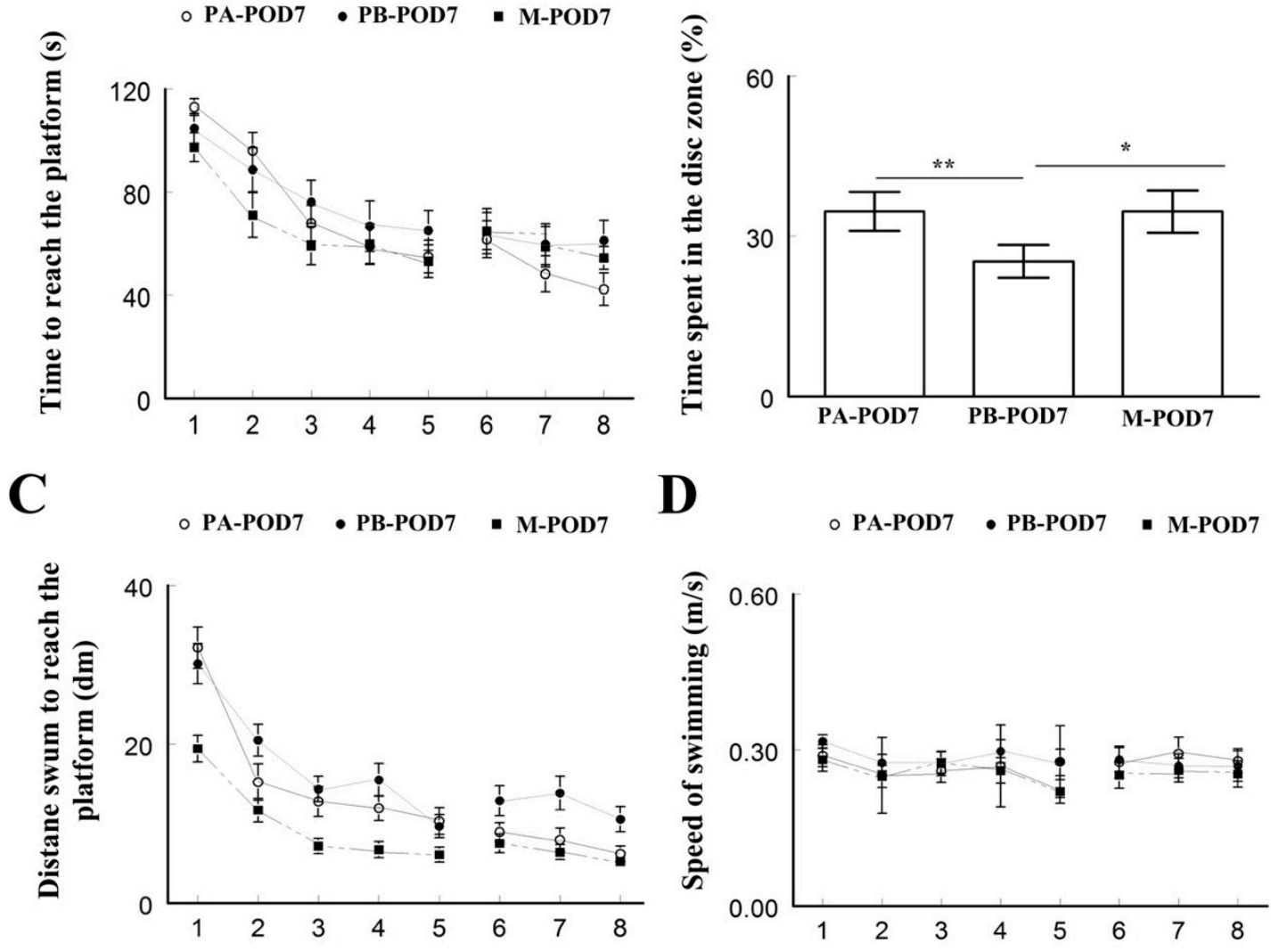

Figure 4. Morris water maze was used to assess for memory (postoperative day 7). (a) Time to reach the platform (latency); (b) time spent in the disc zone; (c) distance swum to reach the platform; and (d) speed of swimming. Sham-operated mice (PA-POD7) and memantine-treated mice (M-POD7) spent less time to reach the platform, more time in the disc zone, and travelled less distance compared to operated-mice that received placebo (PB-POD7). No significant differences were found in the speed of swimming between the three groups. Data shown as mean \pm SEM. ${ }^{*} p<0.05,{ }^{* *} p<0.01$.

\subsection{Presence of Anxiety-Like Behavior Following Surgery, with No Improvement in Memantine Groups}

Locomotion and anxiety-like behavior were assessed using the open field test and the elevated plus-maze. In the open field test on postoperative day 1 (Table 3), no significant differences were found between PA-POD1, PB-POD1, and M-POD1 groups in the total distance traveled (number of lines crossed) or in the frequency of central area entry. However, PA-POD1 group spent significantly longer times in the central zone compared to the other groups (Figure 5A). On postoperative day 7 (Table 3), no significant differences were found in the total distance traveled, the frequency of central zone entry, and the total time spent in the central zone (Figure 5B). 
Table 3. The open field test. Data shown as mean $\pm \mathrm{SEM}, p$ values given for $\mathrm{t}$-tests.

\begin{tabular}{cccc}
\hline Group $^{\mathbf{1}}$ & Number of Lines Crossed & Frequency of Central Area Entry & Time Spent at Central Area (s) \\
\hline PA-POD1 & $92.8 \pm 2.9$ & $6.2 \pm 0.6$ & $19.5 \pm 4.3$ \\
PB-POD1 & $105.6 \pm 3.4$ & $6.8 \pm 1$ & $10.5 \pm 1.9^{* *}$ \\
M-POD1 & $99.9 \pm 10.2$ & $6.1 \pm 1.2$ & $6.9 \pm 1.4^{*}$ \\
\hline PA-POD7 & $127.6 \pm 4.6$ & $7.4 \pm 0.9$ & $12.2 \pm 1.3$ \\
PB-POD7 & $119.1 \pm 6.5$ & $8.6 \pm 1.2$ & $14.3 \pm 1.8$ \\
M-POD7 & $122 \pm 11.2$ & $7.6 \pm 1.3$ & $13.7 \pm 2.6$ \\
\hline \multicolumn{4}{r}{${ }^{1}$ Each group $(\mathrm{n}=10) .{ }^{*} p<0.05$ as compared to PA-POD1. ${ }^{* *} p<0.01$ as compared to PA-POD1 }
\end{tabular}
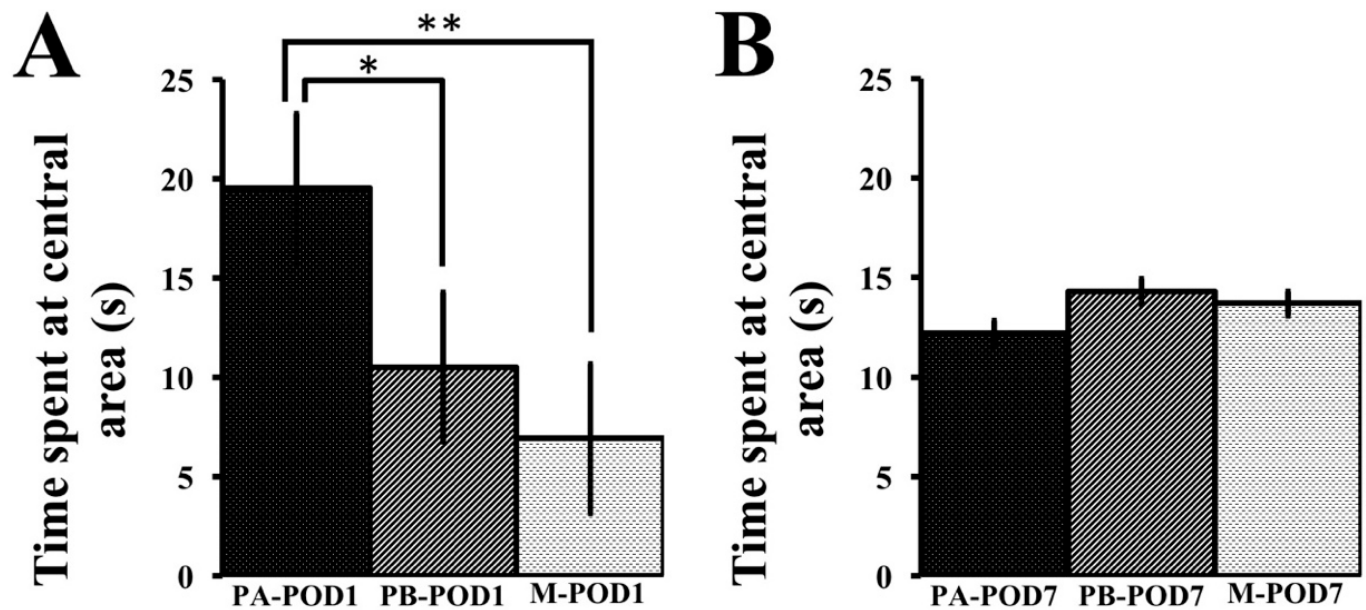

Figure 5. The open field test was used to assess for locomotor function and anxiety. (a) Time spent at central area in seconds (POD1); (b) time spent at central area (POD7). On postoperative day 1 , sham-operated mice (PA-POD1) spent more time in the central area compared to operated-mice (PB-POD1 and M-POD1). On postoperative day 7, no significant differences were found between the three groups. Data shown as mean \pm SEM. ${ }^{*} p<0.05,{ }^{* *} p<0.01$.

In the elevated plus-maze on postoperative day 1 (Table 4), mice in the PA-POD1 group spent longer time in the open arms (Figure 6A), and had higher percentages of open arms entries (Figure 6B) compared to PB-POD1 and M-POD1 groups. No significant differences were found in the total number of arm entries. On postoperative day 7 (Table 4), PA-POD7 group spent longer time in the open arms (Figure 6C), and had higher percentages of open arms entries (Figure 6D) compared to the other two groups. No significant differences were found in the total number of arm entries.

Table 4. The elevated plus-maze. Data shown as mean $\pm \mathrm{SEM}, p$ values given for t-tests.

\begin{tabular}{cccc}
\hline Group $^{\mathbf{1}}$ & Time Spent in Open Arms (s) & Open Arms Entries (\%) & Total Number of Arm Entries \\
\hline PA-POD1 & $121.3 \pm 6.4$ & $45.7 \pm 2.4$ & $20.7 \pm 0.8$ \\
PB-POD1 & $67.1 \pm 19.5^{*}$ & $32.1 \pm 3.1^{* *}$ & $22.6 \pm 2.4$ \\
M-POD1 & $64.2 \pm 10.5^{* *}$ & $29.4 \pm 2.3^{* *}$ & $21.8 \pm 2$ \\
\hline PA-POD7 & $133.2 \pm 6.9$ & $47.7 \pm 4.6$ & $22.8 \pm 2$ \\
PB-POD7 & $101.5 \pm 7^{+}$ & $31.8 \pm 2.7^{\dagger}$ & $22.9 \pm 1.7$ \\
M-POD7 & $93.1 \pm 6.5^{\dagger}$ & $29.3 \pm 2.4^{\dagger}$ & $25.2 \pm 1.2$ \\
\hline
\end{tabular}

${ }^{1}$ Each group $(\mathrm{n}=10) .{ }^{*} p<0.05$ as compared to PA-POD1. ${ }^{* *} p<0.01$ as compared to PA-POD1. ${ }^{\dagger} p<0.01$ as compared to PA-POD7 

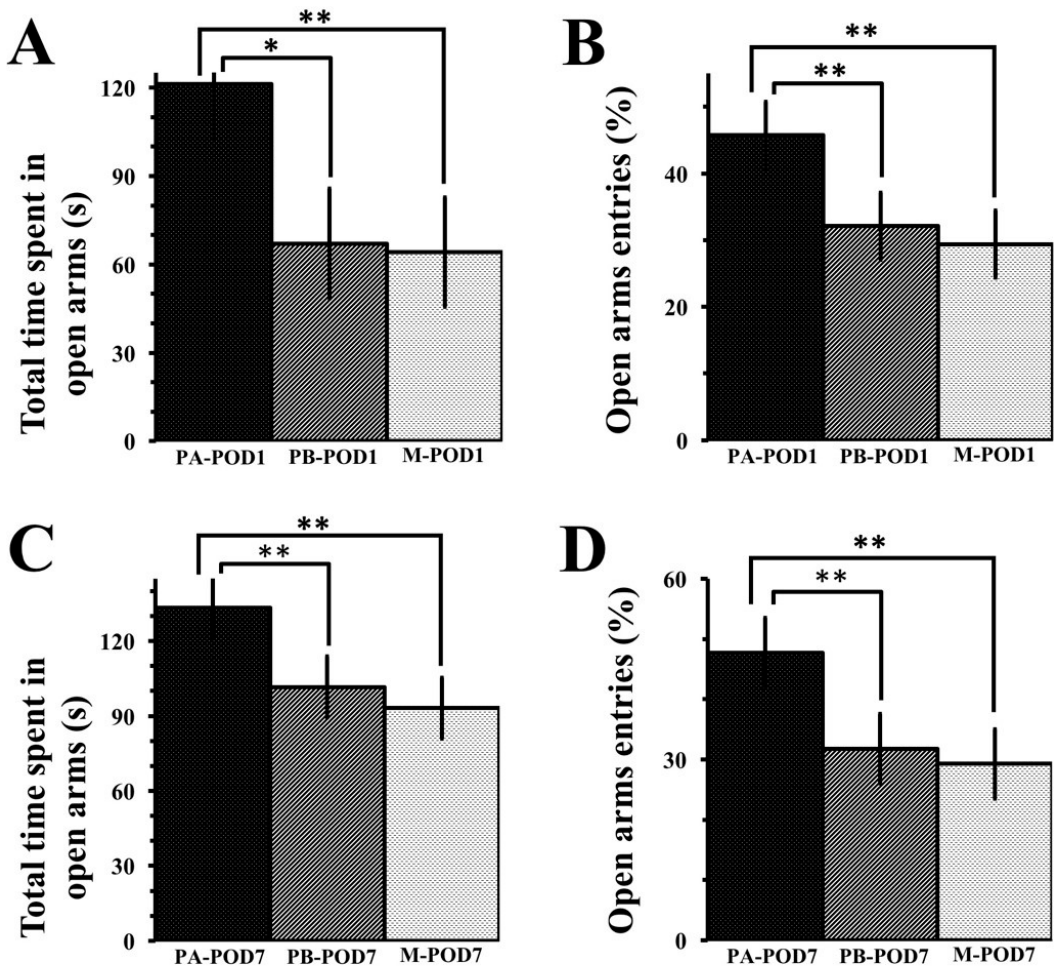

Figure 6. The elevated-plus maze was used to assess for anxiety-like behavior. (a) Total time spent in open arms (POD1); (b) open arms entries (POD1); (c) total time spent in open arms (POD7); (d) open arms entries (POD7). On postoperative days 1 and 7, sham-operated mice (PA-POD1 and PA-POD7) spent more time in the open arms and had higher percentages of open arm entries compared to operated-mice (PB-POD1, PB-POD7, M-POD1 and M-POD7. Data shown as mean \pm SEM. ${ }^{*} p<0.05$, ** $p<0.01$.

\subsection{Presence of Depression-Like Behavior Following Surgery, with Improvement in Memantine Groups}

Depression-like behavior was assessed using the tail-suspension test. On postoperative days 1 (Figure 7A) and 7 (Figure 7B), placebo groups that underwent a laparotomy (PB-POD1 and PB-POD7) showed depression-like behavior compared to sham-operated mice (PA-POD1 and PA-POD7) and memantine-treated mice (M-POD1 and M-POD7), as they had higher immobility times (Table 5).
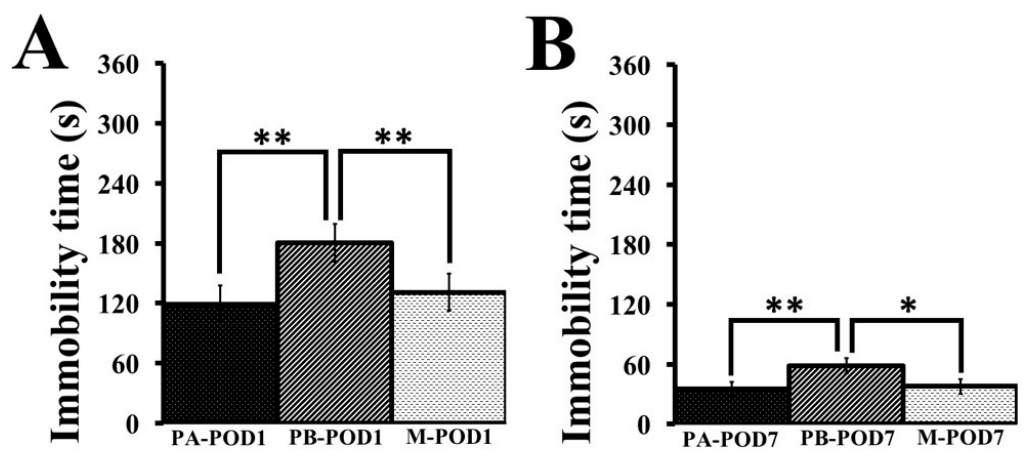

Figure 7. The tail-suspension test was used to assess depression-like behavior (postoperative days 1 and 7). (A) Immobility time (POD1); and (B) immobility time (POD7). On postoperative days 1 and 7, placebo groups (PB-POD1 and PB-POD7) showed depression-like behavior compared to sham-operated mice (PA-POD1 and PA-POD7) and memantine-treated mice (M-POD1 and M-POD7), as they had higher immobility times. Data shown as mean \pm SEM. ${ }^{*} p<0.05,{ }^{* *} p<0.01$. 
Table 5. The tail-suspension test. Data shown as mean $\pm \mathrm{SEM}, p$ values given for t-tests.

\begin{tabular}{ccc}
\cline { 2 - 2 } Group ${ }^{1}$ & Immobility Time (s) \\
\cline { 2 - 2 } PA-POD1 & $119.1 \pm 16.4$ \\
PB-POD1 & $180.3 \pm 3.5^{* *}$ \\
M-POD1 & $131 \pm 9.2$ \\
\hline PA-POD7 & $34.8 \pm 4.3$ \\
PB-POD7 & $58.3 \pm 6.2^{\dagger}$ \\
M-POD7 & $37.6 \pm 5.9$ \\
\hline${ }^{1}$ Each group $(n=10) .{ }^{* *} p<0.05$ as compared to PA-POD ${ }^{\dagger} \cdot{ }^{\dagger} p<0.05$ as compared to PA-POD7.
\end{tabular}

\subsection{Improved Preference for Social Novelty with Memantine on Postopeartive Day 1}

In the three-chamber social apparatus, normal levels of sociability were observed on postoperative day 1 (Table 6), as mice in session 1 (Figure 8A) spent more time in the chamber containing the caged mouse than the empty one, in all three groups; PA-POD1, PB-POD1 and M-POD1. In session 2 (Figure 8B), PA-POD1 and M-POD1 demonstrated preference for social novelty, as mice spent more time in the chamber containing the novel mouse than the chamber containing the already investigated mouse. By contrast, mice in the PB-POD1 did not show preference for social novelty, as they did not spend significantly different times in the chambers in session 2. No significant differences were found in the number of entries to the two chambers for all groups, both in session 1 and 2 (Table 7).

On postoperative day 7 (Table 6), normal levels of sociability were observed in all three groups in session 1 (Figure 8C); and in session 2 (Figure 8D), with no significant differences in the number of entries to the chambers (Table 7).

Table 6. Time spent in chambers in the three-chamber test. Data shown as mean \pm SEM, $p$ values given for t-tests.

\begin{tabular}{ccccc}
\hline \multirow{2}{*}{ Group $^{1}$} & \multicolumn{2}{c}{ Session 1 } & \multicolumn{2}{c}{ Session 2 } \\
\cline { 2 - 5 } & Time with Mouse (s) & Time without Mouse (s) & Time with Old Mouse (s) & Time with New Mouse (s) \\
\hline PA-POD1 & $299.7 \pm 20.8^{* *}$ & $190 \pm 21.4$ & $190.2 \pm 14$ & $290 \pm 18.2^{t+}$ \\
PB-POD1 & $286.1 \pm 25^{*}$ & $209 \pm 31.3$ & $259.6 \pm 22.2$ & $272.5^{*} \pm 22$ \\
M-POD1 & $309.7 \pm 28^{* *}$ & $193 \pm 24.6$ & $170 \pm 18.4$ & $345.2^{++} 26.7^{++}$ \\
\hline PA-POD7 & $314.4 \pm 20^{* *}$ & $176 \pm 22.2$ & $233.4 \pm 28.8$ & $280 \pm 22^{++}$ \\
PB-POD7 & $325 \pm 22.1^{* *}$ & $178.2 \pm 19.9$ & $232 \pm 22$ & $288.4^{*+} \pm 26.6^{++}$ \\
M-POD7 & $322.2 \pm 26.2^{* *}$ & $178 \pm 19.2$ & $225.3 \pm 26.1$ & $277.2 \pm 25^{++}$ \\
\hline
\end{tabular}

${ }^{1}$ Each group $(\mathrm{n}=10) .{ }^{*} p<0.05$ as compared to time without mouse. ${ }^{* *} p<0.01$ as compared to time without mouse.

${ }^{++} p<0.01$ as compared to time with old mouse 

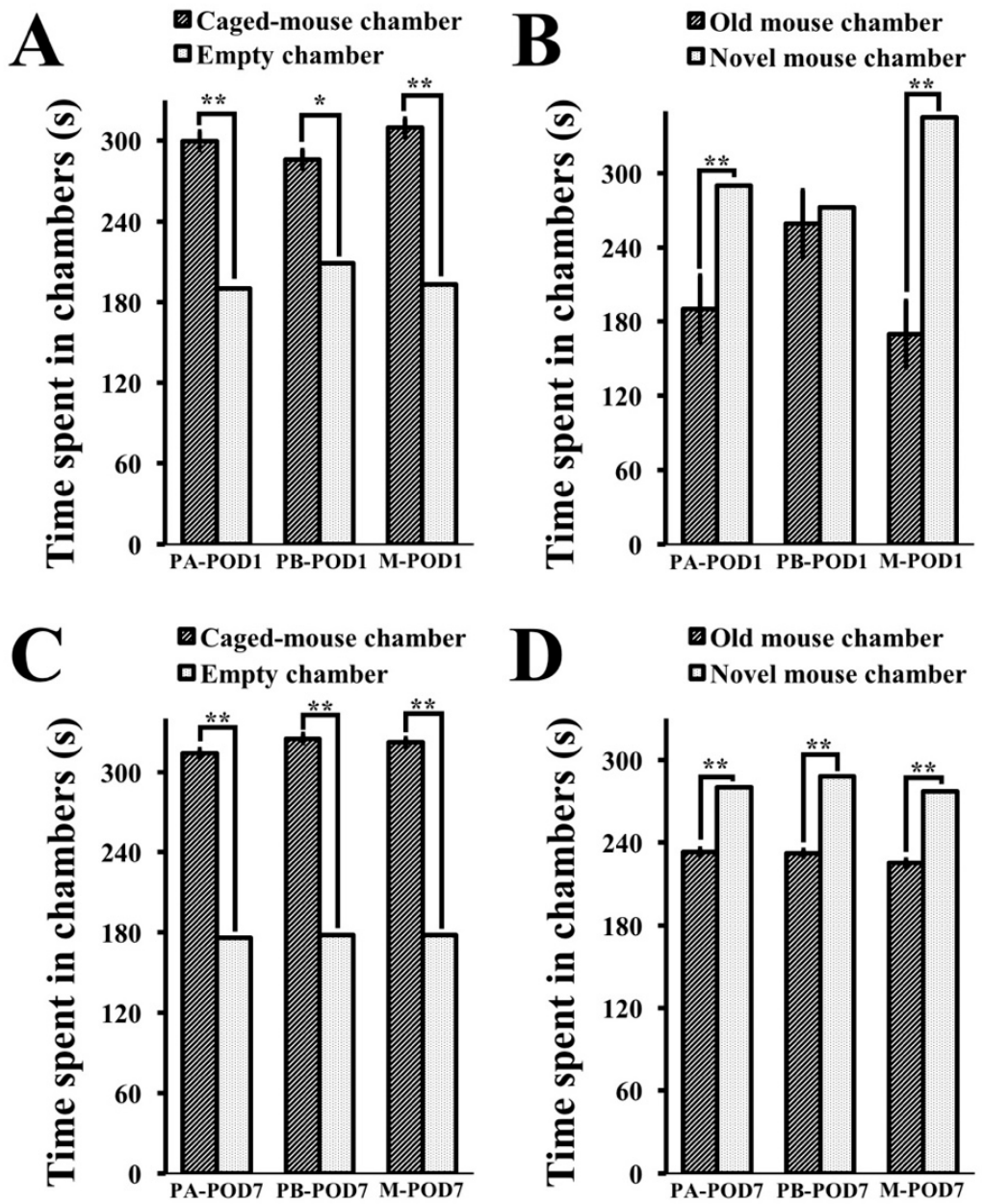

Figure 8. The three-chamber test was used to assess sociability and preference for social novelty. (a) Time spent in chambers in session 1 (POD1); (b) time spent chambers in session 2 (POD1); (c) time spent in chambers in session 1 (POD7); and (d) time spent in chambers in session 2 (POD7). On postoperative day 1 , mice in all three groups showed normal sociability as they spent more time in the chamber containing the caged-mouse (session 1). Preference for social novelty (session 2) was observed in PA-POD1 and M-POD1 as mice spent more time in the chamber containing the new mouse, while PB-POD1 did show a preference for social novelty. On postoperative day 7, mice in all three groups showed normal sociability (session 1 ) and preference for social novelty (session 2 ). Data shown as mean \pm SEM. ${ }^{*} p<0.05,{ }^{* *} p<0.01$.

Table 7. Frequency of entry to chambers in the three-chamber test. Data shown as mean \pm SEM.

\begin{tabular}{ccccc}
\hline \multirow{2}{*}{ Group $^{1}$} & \multicolumn{3}{c}{ Session 1 } & \multicolumn{2}{c}{ Session 2 } \\
\cline { 2 - 5 } & Chamber with Mouse & Chamber without Mouse & Chamber with Old Mouse & Chamber with New Mouse \\
\hline PA-POD1 & $7.3 \pm 0.6$ & $7.9 \pm 1.4$ & $7.7 \pm 0.5$ & $8.7 \pm 0.4$ \\
PB-POD1 & $6.4 \pm 0.8$ & $5.4 \pm 0.7$ & $9.9 \pm 1.5$ & $10.4 \pm 1.8$ \\
M-POD1 & $8.3 \pm 0.6$ & $7.1 \pm 1$ & $8.4 \pm 0.7$ & $7.9 \pm 0.4$ \\
\hline PA-POD7 & $7.4 \pm 0.5$ & $5.8 \pm 1$ & $6.9 \pm 0.4$ & $7 \pm 0.5$ \\
PB-POD7 & $7.2 \pm 0.6$ & $6.1 \pm 0.4$ & $6.5 \pm 0.4$ & $7.6 \pm 0.4$ \\
M-POD7 & $12 \pm 1.2$ & $14.6 \pm 1.5$ & $13.4 \pm 0.9$ & $14.3 \pm 1.4$ \\
\hline \multicolumn{5}{r}{}
\end{tabular}

\section{Discussion}

The purpose of this study is to examine the effect of memantine on a spectrum of cognitive functions postoperatively. Hovens and colleagues [14] point to a translational gap in postoperative 
cognitive dysfunction (POCD) research. POCD is often reported by clinical studies without specifying what cognitive functions or brain structures are involved. Memory, concentration, language comprehension, and information processing are commonly implicated, but only few studies employ neurophysiological testing to make distinctions between these cognitive domains (see [45-47] for examples). On the other hand, pre-clinical research using animal models mostly focused on memory and hippocampal injury, and neglected other aspects of cognition. Taking that into consideration, we attempted to investigate the effect of surgery on different aspects of cognition in mice. These include learning and memory, anxiety, locomotor function, depression, sociability and preference for social novelty.

With regards to body weight, mice that underwent surgery (PB and M groups) suffered from weight loss on postoperative days 1 and 3, but regained their weight on postoperative day 7 . Weight loss in the first few days after surgery in POCD models is commonly reported [48,49], and it could be attributed to dehydration and fluid loss during surgery.

Learning and memory were assessed using the Morris water maze test. On postoperative days 1 and 7, mice that underwent surgery (PB-POD1 and PB-POD7) spent more time and travelled more distance to reach the platform, and spent less time in the disc zone in the probe test, compared to the groups that received anesthesia and analgesia without surgery (PA-POD1 and PA-POD7). Motor function was not affected, as all groups had similar speed of swimming. These findings suggest impaired learning and memory in mice following surgery. Several studies reported similar findings [48,50]. The duration of memory impairment following surgery varies in animal models of POCD. Most studies reported effects lasting between 1 and 7 days [23,24,38,51]. However, effects lasting for more than 1 week have also been reported [24,48,52]. In our study, memory was not tested beyond one week and, therefore, it is not possible, based on these findings, to determine whether these deficits are persistent or not.

The abdominal surgery performed on mice in this study is considered minor surgery. The surgical model used [38] was shown to lead to increased inflammatory changes in the hippocampus of aged mice (23-25 months old), but not in young adult mice (4-6 months old). Moreover, it did not result in significantly impaired performance in a reversal learning version of the Morris water maze. In our study, adult mice (aged 4-6 months) were tested. Interestingly, significant memory impairment was observed. This discrepancy could be attributed to the version of the Morris water maze test used. The standard Morris water maze, which tests spatial learning through visual cues with a probe test, is considered reflective of hippocampal function [53,54]. On the other hand, some variations of the Morris water maze, such as reversal tasks, are thought to be independent of hippocampal function [54,55]. Our findings support previous research, which have suggested that hippocampal-dependent memory is specifically susceptible to surgery-induced impairments $[23,48,51,52,56]$.

Anxiety may inhibit exploratory behavior in mice [57], as well as performance in other cognitive tests. Anxiety-like behavior was assessed using the open field test and the elevated-plus maze. On postoperative day 1 , sham-operated mice (PA-POD1) spent more time in the central area in the open field, and more time in the open arms of the elevated-plus maze with a higher number of entries to the open arms, compared to mice that underwent surgery (PB-POD1). On postoperative day 7 , no significant differences were found in the open field test. However, sham-operated mice (PA-POD7) spent more time in the open arms of the elevated-plus maze with higher number of entries to the open arms compared to their surgical counterpart (PB-POD7). Collectively, these observations may reflect anxiety-like behavior and reduced interest in the environment. Several studies reported anxiety-like behavior following surgery [48,58-60], but mostly in the first two postoperative days. Because of that, anxiety in this context is often viewed as a transient response to acute illness or trauma $[48,61,62]$, rather than a persistent cognitive deficit related to POCD. In our experiment, however, anxiety was observed on days 1 and 7 postoperatively. It is unclear whether this anxiety reflects a sickness-response to trauma, or is related to inflammatory changes in the brain, as no inflammatory assays were performed. 
Decreased social activity following surgery has been reported previously by human studies $[58,63]$, and animal models of peripheral inflammation $[64,65]$ However, there is a lack of studies concerning sociability and social novelty following surgery in mice. In this study, sociability and preference for social novelty were assessed using the three-chamber test. Mice that underwent surgery (PB-POD1) exhibited normal sociability and no preference for social novelty on postoperative day 1. On postoperative day 7, operated mice (PB-POD7) showed normal sociability and preference for social novelty. Overall, these findings suggest normal social behavior in mice following surgery.

Depression was assessed using the tail-suspension test. Mice that underwent surgery (PB-POD1 and PB-POD7) showed depression-like behavior on postoperative days 1 and 7, as they had higher immobility times compared to their non-surgical counterparts (PA-POD1 and PA-POD7). Animal models of peripheral inflammation reported depression-like behavior, and attributed the phenomenon to a high turnover rate of brain serotonin as a result of an exaggerated elevation in inflammatory mediators in the brain $[66,67]$. On the contrary, depression was not shown to occur after surgery in humans $[8,68,69]$, but it is considered to be a risk factor for POCD [47] and postoperative delirium [70,71].

As mentioned, the pathophysiology underlying POCD is not yet fully understood, and several etiological factors have been proposed. Hypocarbia due to hyperventilation during anesthesia was shown to prolong cognitive dysfunction after surgery [72], but other studies failed to establish the link $[73,74]$. Prolonged hypotension in the perioperative period was thought to result in cerebral hypoperfusion, and subsequently cognitive decline. However, the effect was not shown to be important [8,75-77]. Cognitive decline is well-documented following cardiac surgery [78-80], as it could be a source of microemboli (clots, fat, or air bubbles) that causes brain infarcts. However, POCD is often found following non-cardiac surgeries, and the presence of microemboli is not clearly linked to cognitive dysfunction $[17,81,82]$. Sleep disturbances following surgery can affect cognitive function, but evidence for such an effect is scarce [83]. Neurodegeneration can occur as a result of the use of volatile anesthetics, as shown by animal studies [84-86], but several other studies failed to find a link $[17,22,23,38,87]$. Other etiologies, including anticholinergic activity of medications routinely used in the perioperative period, and low intraoperative cerebral oxygenation, were also proposed, but the results were inconclusive [15].

Consistent evidence exists only for the role of postoperative peripheral inflammation in causing exaggerated neuroinflammatory responses in the brain, that manifest as cognitive decline. Severe systemic inflammation, as a result of trauma or infection, is known to affect the central nervous system (CNS) [88-90], and surgery was shown to result in the systemic release of inflammatory mediators, such as cytokines, reactive oxygen species, and endothelins [14,91-95]. These changes lead to the activation of microglia in the CNS, which results in the release of cytokines and other inflammatory mediators that have been linked to cognitive dysfunction [19-21,23,96,97]. Moreover, the severity of the surgical intervention is correlated to the risk of cognitive dysfunction postoperatively, which supports the inflammatory hypothesis, as more severe procedures are related to higher magnitudes of immune activation $[14,17,23,24,98-100]$.

Interestingly, these neuroinflammatory responses also lead to neurodegenerative changes, such as tau phosphorylation, cytokine-induced glutamatergic excitotoxicity, synaptic impairment, and most importantly, beta-amyloid accumulation, which are also characteristic of Alzheimer's disease $[22,25,26,101,102]$. It comes as no surprise that POCD have been linked to an increased risk of developing dementia [12] and, therefore, both entities can be viewed as manifestations of the same process [15]. It should be noted that the absence of neurofibrillary tangles in POCD distinguishes it from Alzheimer's disease. Therefore, cognitive deficits in POCD are thought to be specifically related to beta-amyloid accumulation [25]. Beta-amyloid proteins are known to induce neuronal cell degeneration and apoptosis, especially in the hippocampus, resulting in memory impairment [102]. Additionally, amyloid precursor protein (APP), whose proteolysis leads to the generation of beta-amyloid proteins and acts as an acute reactive protein during stress $[103,104]$, was also found to be increased following surgery in mice [25]. 
Management of POCD is centered around preventive measures. It involves identifying those who are at risk, and optimizing perioperative physical and mental health. Several measures have been shown to reduce the incidence of POCD [18,27-29,105-107]. These include improving sleep hygiene in the perioperative period, having shorter periods of fasting before surgery, increasing the frequency of social contact with family and friends after surgery, optimization of nutritional status and hydration, selecting the least invasive procedures possible, and adequate pain control.

However, no effective pharmacological treatment exists. Research in this area focused mostly on anti-inflammatory medications, since neuroinflammation contributes to POCD significantly. For example, the administration of small doses of ketamine, which has an anti-inflammatory effect, was shown to reduce the incidence of POCD [108]. Minocycline [23,109], a derivative of tetracycline, and berberine [49], an isoquinoline alkaloid, were also shown to reduce neuroinflammation in mice. In Alzheimer's disease, the use of non-steroidal anti-inflammatory medications has been shown to attenuate disease progression in the early stages [110].

In the present study, we hypothesized that memantine, an NMDAR antagonist, that is shown to be effective in treating Alzheimer's disease [30-34], might have a protective effect against POCD. The release of pro-inflammatory cytokines in the CNS leads to an increase in the levels of glutamate, which increases NMDAR activity. That, in turn, increases $\mathrm{Ca}^{2+}$ inflow through ion channels, which results in pathological over-excitation, and ultimately neuronal death. Furthermore, hyper-activation of NMDARs has also been associated with tau toxicity [111]. As mentioned previously, both of these processes, glutamatergic excitotoxicity and tau phosphorylation, have been shown to occur in Alzheimer's disease and in POCD [25]. Memantine inhibits NMDARs by blocking the $\mathrm{Ca}^{2+}$ ion channel, and thus it targets both of the pathological processes that are known to be involved in POCD. Previous research also showed that memantine reduces neuroinflamamtion in animal models and improves cognitive function [112-114]. In our study, memantine improved the preference for social novelty, and had an anti-depressant-like effect, with no effect on memory or anxiety-like behavior on postoperative day 1 . On day 7 postoperatively, memantine had a positive effect on memory and depression. In addition, memantine did not impact the body weight of treated mice. In humans, a randomized clinical trial conducted by Ghaffary and colleagues [115] showed that the pre-operative administration of memantine protected patients from POCD following cardiac surgeries, and improved cognitive function after 3 months postoperatively. Collectively, these findings suggest that memantine has the potential to prevent POCD in humans.

\section{Conclusions}

The findings of this study suggest a protective effect of memantine on memory, preference for social novelty, and depression-like behavior in mice following surgery. However, the study offers a coarse behavioral assay in mice, and further research is recommended to address the mechanisms by which memantine impacts POCD, and the feasibility of using it in humans.

Author Contributions: Conceptualization, A.A., M.R., and A.K.; Formal analysis, A.A., M.R., S.A. and A.K.; Investigation, A.A., M.R. and S.A.; Methodology, A.A., M.R., and A.K.; Supervision, A.K.; Writing-original draft, A.A. and M.R.; Writing-review and editing, A.A., and M.R.

Funding: This research received no external funding.

Acknowledgments: There are no acknowledgments.

Conflicts of Interest: The authors declare no conflict of interest.

\section{References}

1. Bedford, P.D. Adverse cerebral effects of anaesthesia on old people. Lancet 1955, 269, 259-263. [CrossRef]

2. Shaw, P.J.; Bates, D.; Cartlidge, N.E.F.; French, J.M.; Heaviside, D.; Julian, D.G.; Shaw, D.A. Long-term Intellectual Dysfunction Following Coronary Artery Bypass Graft Surgery: A Six Month Follow-up Study. QJM Int. J. Med. 1987, 62, 259-268. [CrossRef] 
3. Newman, S. The incidence and nature of neuropsychological morbidity following cardiac surgery. Perfusion 1989, 4, 93-100. [CrossRef]

4. Newman, M.F.; Croughwell, N.D.; Blumenthal, J.A.; White, W.D.; Lewis, J.B.; Smith, L.R.; Frasco, P.; Towner, E.A.; Schell, R.M.; Hurwitz, B.J. Effect of aging on cerebral autoregulation during cardiopulmonary bypass. Association with postoperative cognitive dysfunction. Circulation 1994, 90, II243-9. [PubMed]

5. Kolkka, R.; Hilberman, M. Neurologic dysfunction following cardiac operation with low-flow, low-pressure cardiopulmonary bypass. J. Thorac. Cardiovasc. Surg. 1980, 79, 432-437. [PubMed]

6. Gilman, S. Cerebral Disorders after Open-Heart Operations. N. Engl. J. Med. 1965, 272, 489-498. [CrossRef] [PubMed]

7. Tufo, H.M.; Ostfeld, A.M.; Shekelle, R. Central Nervous System Dysfunction Following Open-Heart Surgery. JAMA J. Am. Med. Assoc. 1970, 212, 1333. [CrossRef]

8. Moller, J.T.; Cluitmans, P.; Rasmussen, L.S.; Houx, P.; Rasmussen, H.; Canet, J.; Rabbitt, P.; Jolles, J.; Larsen, K.; Hanning, C.D.; et al. Long-term postoperative cognitive dysfunction in the elderly: ISPOCD1 study. Lancet 1998, 351, 857-861. [CrossRef]

9. Canet, J.; Raeder, J.; Rasmussen, L.S.; Enlund, M.; Kuipers, H.M.; Hanning, C.D.; Jolles, J.; Korttila, K.; Siersma, V.D.; Dodds, C.; et al. Cognitive dysfunction after minor surgery in the elderly. Acta Anaesthesiol. Scand. 2003, 47, 1204-1210. [CrossRef] [PubMed]

10. Steinmetz, J.; Funder, K.S.; Dahl, B.T.; Rasmussen, L.S. Depth of anaesthesia and post-operative cognitive dysfunction. Acta Anaesthesiol. Scand. 2010, 54, 162-168. [CrossRef] [PubMed]

11. Rasmussen, L.S.; Johnson, T.; Kuipers, H.M.; Kristensen, D.; Siersma, V.D.; Vila, P.; Jolles, J.; Papaioannou, A.; Abildstrom, H.; Silverstein, J.H.; et al. Does anaesthesia cause postoperative cognitive dysfunction? A randomised study of regional versus general anaesthesia in 438 elderly patients. Acta Anaesthesiol. Scand. 2003, 47, 260-266. [CrossRef] [PubMed]

12. Vanderweyde, T.; Bednar, M.M.; Forman, S.A.; Wolozin, B. Iatrogenic Risk Factors for Alzheimer's Disease: Surgery and Anesthesia. J. Alzheimer's Dis. 2010, 22, S91-S104. [CrossRef] [PubMed]

13. Monk, T.G.; Weldon, B.C.; Garvan, C.W.; Dede, D.E.; van der Aa, M.T.; Heilman, K.M.; Gravenstein, J.S. Predictors of Cognitive Dysfunction after Major Noncardiac Surgery. Anesthesiology 2008, 108, 18-30. [CrossRef] [PubMed]

14. Hovens, I.B.; Schoemaker, R.G.; van der Zee, E.A.; Heineman, E.; Izaks, G.J.; van Leeuwen, B.L. Thinking through postoperative cognitive dysfunction: How to bridge the gap between clinical and pre-clinical perspectives. Brain Behav. Immun. 2012, 26, 1169-1179. [CrossRef] [PubMed]

15. Grape, S.; Ravussin, P.; Rossi, A.; Kern, C.; Steiner, L.A. Postoperative cognitive dysfunction. Trends Anaesth. Crit. Care 2012, 2, 98-103. [CrossRef]

16. Funder, K.S.; Steinmetz, J.; Rasmussen, L.S. Methodological issues of postoperative cognitive dysfunction research. Semin. Cardiothorac. Vasc. Anesth. 2010, 14, 119-122. [CrossRef] [PubMed]

17. Krenk, L.; Rasmussen, L.S.; Kehlet, H. New insights into the pathophysiology of postoperative cognitive dysfunction. Acta Anaesthesiol. Scand. 2010, 54, 951-956. [CrossRef] [PubMed]

18. Deiner, S.; Silverstein, J.H. Postoperative delirium and cognitive dysfunction. Br. J. Anaesth. 2009, 103, 41-46. [CrossRef] [PubMed]

19. Beloosesky, Y.; Hendel, D.; Weiss, A.; Hershkovitz, A.; Grinblat, J.; Pirotsky, A.; Barak, V. Cytokines and C-reactive protein production in hip-fracture-operated elderly patients. J. Gerontol. A Biol. Sci. Med. Sci. 2007, 62, 420-426. [CrossRef] [PubMed]

20. Ramlawi, B.; Rudolph, J.L.; Mieno, S.; Feng, J.; Boodhwani, M.; Khabbaz, K.; Levkoff, S.E.; Marcantonio, E.R.; Bianchi, C.; Sellke, F.W. C-Reactive protein and inflammatory response associated to neurocognitive decline following cardiac surgery. Surgery 2006, 140, 221-226. [CrossRef] [PubMed]

21. Yaffe, K.; Lindquist, K.; Penninx, B.W.; Simonsick, E.M.; Pahor, M.; Kritchevsky, S.; Launer, L.; Kuller, L.; Rubin, S.; Harris, T. Inflammatory markers and cognition in well-functioning African-American and white elders. Neurology 2003, 61, 76-80. [CrossRef] [PubMed]

22. Cao, X.-Z.; Ma, H.; Wang, J.-K.; Liu, F.; Wu, B.-Y.; Tian, A.-Y.; Wang, L.-L.; Tan, W.-F. Postoperative cognitive deficits and neuroinflammation in the hippocampus triggered by surgical trauma are exacerbated in aged rats. Prog. Neuro-Psychopharmacol. Biol. Psychiatry 2010, 34, 1426-1432. [CrossRef] [PubMed] 
23. Cibelli, M.; Fidalgo, A.R.; Terrando, N.; Ma, D.; Monaco, C.; Feldmann, M.; Takata, M.; Lever, I.J.; Nanchahal, J.; Fanselow, M.S.; et al. Role of interleukin-1 $\beta$ in postoperative cognitive dysfunction. Ann. Neurol. 2010, 68, 360-368. [CrossRef] [PubMed]

24. Fidalgo, A.R.; Cibelli, M.; White, J.P.M.; Nagy, I.; Maze, M.; Ma, D. Systemic inflammation enhances surgery-induced cognitive dysfunction in mice. Neurosci. Lett. 2011, 498, 63-66. [CrossRef] [PubMed]

25. Wan, Y.; Xu, J.; Meng, F.; Bao, Y.; Ge, Y.; Lobo, N.; Vizcaychipi, M.P.; Zhang, D.; Gentleman, S.M.; Maze, M.; et al. Cognitive decline following major surgery is associated with gliosis, $\beta$-amyloid accumulation, and $\tau$ phosphorylation in old mice. Crit. Care Med. 2010, 38, 2190-2198. [CrossRef] [PubMed]

26. Bilbo, S.D. Early-life infection is a vulnerability factor for aging-related glial alterations and cognitive decline. Neurobiol. Learn. Mem. 2010, 94, 57-64. [CrossRef] [PubMed]

27. Juliebø, V.; Bjøro, K.; Krogseth, M.; Skovlund, E.; Ranhoff, A.H.; Wyller, T.B. Risk Factors for Preoperative and Postoperative Delirium in Elderly Patients with Hip Fracture. J. Am. Geriatr. Soc. 2009, 57, 1354-1361. [CrossRef]

28. Sciard, D.; Cattano, D.; Hussain, M.; Rosenstein, A. Perioperative management of proximal hip fractures in the elderly: The surgeon and the anesthesiologist. Minerva Anestesiol. 2011, 77, 715-722. [PubMed]

29. Egerod, I.; Rud, K.; Specht, K.; Jensen, P.S.; Trangbaek, A.; Rønfelt, I.; Kristensen, B.; Kehlet, H. Room for improvement in the treatment of hip fractures in Denmark. Dan. Med. Bull. 2010, 57, A4199. [PubMed]

30. Minkeviciene, R.; Banerjee, P.; Tanila, H. Memantine Improves Spatial Learning in a Transgenic Mouse Model of Alzheimer's Disease. J. Pharmacol. Exp. Ther. 2004, 311, 677-682. [CrossRef] [PubMed]

31. Holmes, G.L. Cognitive impairment in epilepsy: The role of network abnormalities. Epileptic Disord. 2015, 17, 101-116. [CrossRef] [PubMed]

32. Van Dam, D.; De Deyn, P.P. Cognitive evaluation of disease-modifying efficacy of Galantamine and Memantine in the APP23 model. Eur. Neuropsychopharmacol. 2006, 16, 59-69. [CrossRef] [PubMed]

33. Reisberg, B.; Doody, R.; Stöffler, A.; Schmitt, F.; Ferris, S.; Möbius, H.J.; Memantine Study Group. Memantine in Moderate-to-Severe Alzheimer's Disease. N. Engl. J. Med. 2003, 348, 1333-1341. [CrossRef] [PubMed]

34. Tariot, P.N.; Farlow, M.R.; Grossberg, G.T.; Graham, S.M.; McDonald, S.; Gergel, I.; Memantine Study Group. Memantine Treatment in Patients With Moderate to Severe Alzheimer Disease Already Receiving Donepezil. JAMA 2004, 291, 317. [CrossRef] [PubMed]

35. Minkeviciene, R.; Banerjee, P.; Tanila, H. Cognition-enhancing and anxiolytic effects of memantine. Neuropharmacology 2008, 54, 1079-1085. [CrossRef] [PubMed]

36. Zajaczkowski, W.; Quack, G.; Danysz, W. Infusion of (+)-MK-801 and memantine-Contrasting effects on radial maze learning in rats with entorhinal cortex lesion. Eur. J. Pharmacol. 1996, 296, 239-246. [CrossRef]

37. Kornhuber, J.; Quack, G. Cerebrospinal fluid and serum concentrations of the N-methyl-D-aspartate (NMDA) receptor antagonist memantine in man. Neurosci. Lett. 1995, 195, 137-139. [CrossRef]

38. Rosczyk, H.A.; Sparkman, N.L.; Johnson, R.W. Neuroinflammation and cognitive function in aged mice following minor surgery. Exp. Gerontol. 2008, 43, 840-846. [CrossRef] [PubMed]

39. Biessels, G.J.; Kamal, A.; Ramakers, G.M.; Urban, I.J.; Spruijt, B.M.; Erkelens, D.W.; Gispen, W.H. Place learning and hippocampal synaptic plasticity in streptozotocin-induced diabetic rats. Diabetes 1996, 45, 1259-1266. [CrossRef] [PubMed]

40. Rajab, E.; Alqanbar, B.; Naiser, M.J.; Abdulla, H.A.; Al-Momen, M.M.; Kamal, A. Sex differences in learning and memory following short-term dietary restriction in the rat. Int. J. Dev. Neurosci. 2014, 36, 74-80. [CrossRef] [PubMed]

41. Gould, T.D. Mood and Anxiety Related Phenotypes in Mice: Characterization Using Behavioral Tests; Humana Press: New York, NY, USA, 2009; ISBN 9781607613039.

42. Komada, M.; Takao, K.; Miyakawa, T. Elevated plus maze for mice. J. Vis. Exp. 2008. [CrossRef] [PubMed]

43. Can, A.; Dao, D.T.; Terrillion, C.E.; Piantadosi, S.C.; Bhat, S.; Gould, T.D. The Tail Suspension Test. JoVE 2012. [CrossRef] [PubMed]

44. Kaidanovich-Beilin, O.; Lipina, T.; Vukobradovic, I.; Roder, J.; Woodgett, J.R. Assessment of social interaction behaviors. J. Vis. Exp. 2011. [CrossRef] [PubMed]

45. Hudetz, J.A.; Patterson, K.M.; Amole, O.; Riley, A.V.; Pagel, P.S. Postoperative cognitive dysfunction after noncardiac surgery: Effects of metabolic syndrome. J. Anesth. 2011, 25, 337-344. [CrossRef] [PubMed] 
46. Bekker, A.; Lee, C.; de Santi, S.; Pirraglia, E.; Zaslavsky, A.; Farber, S.; Haile, M.; de Leon, M.J. Does mild cognitive impairment increase the risk of developing postoperative cognitive dysfunction? Am. J. Surg. 2010, 199, 782-788. [CrossRef] [PubMed]

47. Ancelin, M.L.; de Roquefeuil, G.; Ledésert, B.; Bonnel, F.; Cheminal, J.C.; Ritchie, K. Exposure to anaesthetic agents, cognitive functioning and depressive symptomatology in the elderly. Br. J. Psychiatry 2001, 178, 360-366. [CrossRef] [PubMed]

48. Hovens, I.B.; Schoemaker, R.G.; van der Zee, E.A.; Absalom, A.R.; Heineman, E.; van Leeuwen, B.L. Postoperative cognitive dysfunction: Involvement of neuroinflammation and neuronal functioning. Brain Behav. Immun. 2014, 38, 202-210. [CrossRef] [PubMed]

49. Zhang, Z.; Li, X.; Li, F.; An, L. Berberine alleviates postoperative cognitive dysfunction by suppressing neuroinflammation in aged mice. Int. Immunopharmacol. 2016, 38, 426-433. [CrossRef] [PubMed]

50. Wei, L.; Yao, M.; Zhao, Z.; Jiang, H.; Ge, S. High-fat diet aggravates postoperative cognitive dysfunction in aged mice. BMC Anesthesiol. 2018, 18, 20. [CrossRef] [PubMed]

51. Barrientos, R.M.; Hein, A.M.; Frank, M.G.; Watkins, L.R.; Maier, S.F. Intracisternal Interleukin-1 Receptor Antagonist Prevents Postoperative Cognitive Decline and Neuroinflammatory Response in Aged Rats. J. Neurosci. 2012, 32, 14641-14648. [CrossRef] [PubMed]

52. Kamer, A.R.; Galoyan, S.M.; Haile, M.; Kline, R.; Boutajangout, A.; Li, Y.-S.; Bekker, A. Meloxicam improves object recognition memory and modulates glial activation after splenectomy in mice. Eur. J. Anaesthesiol. 2012, 29, 332-337. [CrossRef] [PubMed]

53. Miyoshi, E.; Wietzikoski, E.C.; Bortolanza, M.; Boschen, S.L.; Canteras, N.S.; Izquierdo, I.; Da Cunha, C. Both the dorsal hippocampus and the dorsolateral striatum are needed for rat navigation in the Morris water maze. Behav. Brain Res. 2012, 226, 171-178. [CrossRef] [PubMed]

54. D'Hooge, R.; De Deyn, P.P. Applications of the Morris water maze in the study of learning and memory. Brain Res. Rev. 2001, 36, 60-90. [CrossRef]

55. Dere, E.; Huston, J.P.; De Souza Silva, M.A. The pharmacology, neuroanatomy and neurogenetics of one-trial object recognition in rodents. Neurosci. Biobehav. Rev. 2007, 31, 673-704. [CrossRef] [PubMed]

56. Vizcaychipi, M.P.; Lloyd, D.G.; Wan, Y.; Palazzo, M.G.; Maze, M.; Ma, D. Xenon Pretreatment May Prevent Early Memory Decline after Isoflurane Anesthesia and Surgery in Mice. PLoS ONE 2011, 6, e26394. [CrossRef] [PubMed]

57. Crawley, J.N. Exploratory behavior models of anxiety in mice. Neurosci. Biobehav. Rev. 1985, 9, 37-44. [CrossRef]

58. Zhang, Y.; Lin, Y.; Liu, Q.; Yuan, X.; Mao, A.; Liu, Y.; Li, Q.; Zheng, J.; Hu, B.; Yu, F. The Effect of Dexmedetomidine on Cognitive Function and Protein Expression of A $\beta$, p-Tau, and PSD95 after Extracorporeal Circulation Operation in Aged Rats. BioMed Res. Int. 2018, 2018, 4014021. [CrossRef] [PubMed]

59. Cheon, S.Y.; Kim, J.M.; Kam, E.H.; Ho, C.-C.; Kim, E.J.; Chung, S.; Jeong, J.-H.; Lee, D.D.-H.; Lee, S.-W.; Koo, B.-N. Cell-penetrating interactomic inhibition of nuclear factor-kappa B in a mouse model of postoperative cognitive dysfunction. Sci. Rep. 2017, 7, 13482. [CrossRef] [PubMed]

60. Karaman, T.; Karaman, S.; Doğru, S.; Tapar, H.; Şahin, A.; Süren, M. Short-Term and Long-Term Effects of Dexamethasone on Cognitive Dysfunction Induced by Sevoflurane in Adult Rats. Turk. J. Anaesthesiol. Reanim. 2017, 45, 158-163. [CrossRef] [PubMed]

61. Dantzer, R.; O'Connor, J.C.; Freund, G.G.; Johnson, R.W.; Kelley, K.W. From inflammation to sickness and depression: When the immune system subjugates the brain. Nat. Rev. Neurosci. 2008, 9, 46-56. [CrossRef] [PubMed]

62. Dantzer, R. Cytokine-induced sickness behavior: Mechanisms and implications. Ann. N. Y. Acad. Sci. 2001, 933, 222-234. [CrossRef] [PubMed]

63. Green, C.M.; Schaffer, S.D. Postoperative cognitive dysfunction in noncardiac surgery: A review. Trends Anaesth. Crit. Care 2018, 24, 40-48. [CrossRef]

64. Lu, S.-M.; Yu, C.-J.; Liu, Y.-H.; Dong, H.-Q.; Zhang, X.; Zhang, S.-S.; Hu, L.-Q.; Zhang, F.; Qian, Y.-N.; Gui, B. S100A8 contributes to postoperative cognitive dysfunction in mice undergoing tibial fracture surgery by activating the TLR4/MyD88 pathway. Brain Behav. Immun. 2015, 44, 221-234. [CrossRef] [PubMed]

65. Dilger, R.N.; Johnson, R.W. Aging, microglial cell priming, and the discordant central inflammatory response to signals from the peripheral immune system. J. Leukoc. Biol. 2008, 84, 932-939. [CrossRef] [PubMed] 
66. Van Harten, A.E.; Scheeren, T.W.L.; Absalom, A.R. A review of postoperative cognitive dysfunction and neuroinflammation associated with cardiac surgery and anaesthesia. Anaesthesia 2012, 67, 280-293. [CrossRef] [PubMed]

67. Godbout, J.P.; Moreau, M.; Lestage, J.; Chen, J.; Sparkman, N.L.; Connor, J.O.; Castanon, N.; Kelley, K.W.; Dantzer, R.; Johnson, R.W. Aging Exacerbates Depressive-like Behavior in Mice in Response to Activation of the Peripheral Innate Immune System. Neuropsychopharmacology 2008, 33, 2341-2351. [CrossRef] [PubMed]

68. Johnson, T.; Monk, T.; Rasmussen, L.S.; Abildstrom, H.; Houx, P.; Korttila, K.; Kuipers, H.M.; Hanning, C.D.; Siersma, V.D.; Kristensen, D.; et al. Postoperative cognitive dysfunction in middle-aged patients. Anesthesiology 2002, 96, 1351-1357. [CrossRef] [PubMed]

69. McKhann, G.M.; Borowicz, L.M.; Goldsborough, M.A.; Enger, C.; Selnes, O.A. Depression and cognitive decline after coronary artery bypass grafting. Lancet 1997, 349, 1282-1284. [CrossRef]

70. Smith, P.J.; Attix, D.K.; Weldon, B.C.; Monk, T.G. Depressive Symptoms and Risk of Postoperative Delirium. Am. J. Geriatr. Psychiatry 2016, 24, 232-238. [CrossRef] [PubMed]

71. Leung, J.M.; Sands, L.P.; Mullen, E.A.; Wang, Y.; Vaurio, L. Are preoperative depressive symptoms associated with postoperative delirium in geriatric surgical patients? J. Gerontol. A Biol. Sci. Med. Sci. 2005, 60, 1563-1568. [CrossRef] [PubMed]

72. Wollman, S.B.; Orkin, L.R. Postoperative human reaction time and hypocarbia during anaesthesia. Br. J. Anaesth. 1968, 40, 920-926. [CrossRef] [PubMed]

73. Blenkarn, G.D.; Briggs, G.; Bell, J.; Sugioka, K. Cognitive function after hypocapnic hyperventilation. Anesthesiology 1972, 37, 381-386. [CrossRef] [PubMed]

74. Murrin, K.R.; Nagarajan, T.M. Hyperventilation and psychometric testing. A preliminary study. Anaesthesia 1974, 29, 50-58. [CrossRef] [PubMed]

75. Thompson, G.E.; Miller, R.D.; Stevens, W.C.; Murray, W.R. Hypotensive anesthesia for total hip arthroplasty: A study of blood loss and organ function (brain, heart, liver, and kidney). Anesthesiology 1978, 48, 91-96. [CrossRef] [PubMed]

76. Rollason, W.N.; Robertson, G.S.; Cordiner, C.M.; Hall, D.J. A comparison of mental function in relation to hypotensive and normotensive anaesthesia in the elderly. Br. J. Anaesth. 1971, 43, 561-566. [CrossRef] [PubMed]

77. Eckenhoff, J.E.; Compton, J.R.; Larson, A.; Davies, R.M. Assessment of cerebral effects of deliberate hypotension by psychological measurements. Lancet 1964, 2, 711-714. [CrossRef]

78. Stump, D.A.; Rogers, A.T.; Hammon, J.W.; Newman, S.P. Cerebral emboli and cognitive outcome after cardiac surgery. J. Cardiothorac. Vasc. Anesth. 1996, 10, 113-118. [CrossRef]

79. Knipp, S.C.; Matatko, N.; Wilhelm, H.; Schlamann, M.; Thielmann, M.; Lösch, C.; Diener, H.C.; Jakob, H. Cognitive Outcomes Three Years after Coronary Artery Bypass Surgery: Relation to Diffusion-Weighted Magnetic Resonance Imaging. Ann. Thorac. Surg. 2008, 85, 872-879. [CrossRef] [PubMed]

80. Moody, D.M.; Brown, W.R.; Challa, V.R.; Stump, D.A.; Reboussin, D.M.; Legault, C. Brain microemboli associated with cardiopulmonary bypass: A histologic and magnetic resonance imaging study. Ann. Thorac. Surg. 1995, 59, 1304-1307. [CrossRef]

81. Koch, S.; Forteza, A.; Lavernia, C.; Romano, J.G.; Campo-Bustillo, I.; Campo, N.; Gold, S. Cerebral Fat Microembolism and Cognitive Decline After Hip and Knee Replacement. Stroke 2007, 83, 1079-1081. [CrossRef] [PubMed]

82. Hindman, B.J. Emboli, inflammation, and CNS impairment: An overview. Heart Surg. Forum 2002, 5, $249-253$. [PubMed]

83. Gögenur, I. Postoperative circadian disturbances. Dan. Med. Bull. 2010, 57, B4205. [PubMed]

84. Culley, D.J.; Baxter, M.G.; Crosby, C.A.; Yukhananov, R.; Crosby, G. Impaired Acquisition of Spatial Memory 2 Weeks After Isoflurane and Isoflurane-Nitrous Oxide Anesthesia in Aged Rats. Anesth. Analg. 2004, 99, 1393-1397. [CrossRef] [PubMed]

85. Kalenka, A.; Gross, B.; Maurer, M.H.; Thierse, H.-J.; Feldmann, R.E. Isoflurane Anesthesia Elicits Protein Pattern Changes in Rat Hippocampus. J. Neurosurg. Anesthesiol. 2010, 22, 144-154. [CrossRef] [PubMed]

86. Papaioannou, A.; Fraidakis, O.; Michaloudis, D.; Balalis, C.; Askitopoulou, H. The impact of the type of anaesthesia on cognitive status and delirium during the first postoperative days in elderly patients. Eur. J. Anaesthesiol. 2005, 22, 492-499. [CrossRef] [PubMed] 
87. Newman, S.; Stygall, J.; Hirani, S.; Shaefi, S.; Maze, M. Postoperative Cognitive Dysfunction after Noncardiac. Anesthesiology 2007, 106, 572-590. [CrossRef] [PubMed]

88. Young, G.B.; Bolton, C.F.; Archibald, Y.M.; Austin, T.W.; Wells, G.A. The electroencephalogram in sepsis-associated encephalopathy. J. Clin. Neurophysiol. 1992, 9, 145-152. [CrossRef] [PubMed]

89. Allan, S.M.; Rothwell, N.J. Cytokines and acute neurodegeneration. Nat. Rev. Neurosci. 2001, 2, 734-744. [CrossRef] [PubMed]

90. Yirmiya, R.; Goshen, I. Immune modulation of learning, memory, neural plasticity and neurogenesis. Brain Behav. Immun. 2011, 25, 181-213. [CrossRef] [PubMed]

91. Börgermann, J.; Scheubel, R.J.; Simm, A.; Silber, R.E.; Friedrich, I. Inflammatory response in on- versus off-pump myocardial revascularization: Is ECC really the culprit? Thorac. Cardiovasc. Surg. 2007, 55, 473-480. [CrossRef] [PubMed]

92. Jungwirth, B.; Eckel, B.; Blobner, M.; Kellermann, K.; Kochs, E.F.; Mackensen, G.B. The impact of cardiopulmonary bypass on systemic interleukin-6 release, cerebral nuclear factor-kappa B expression, and neurocognitive outcome in rats. Anesth. Analg. 2010, 110, 312-320. [CrossRef] [PubMed]

93. Giannoudis, P.V.; Dinopoulos, H.; Chalidis, B.; Hall, G.M. Surgical stress response. Injury 2006, 37, S3-S9. [CrossRef]

94. Karlidag, R.; Unal, S.; Sezer, O.H.; Bay Karabulut, A.; Battaloğlu, B.; But, A.; Ozcan, C. The role of oxidative stress in postoperative delirium. Gen. Hosp. Psychiatry 2006, 28, 418-423. [CrossRef] [PubMed]

95. Levy, J.H.; Tanaka, K.A. Inflammatory response to cardiopulmonary bypass. Ann. Thorac. Surg. 2003, 75, S715-20. [CrossRef]

96. Lucin, K.M.; Wyss-Coray, T. Immune Activation in Brain Aging and Neurodegeneration: Too Much or Too Little? Neuron 2009, 64, 110-122. [CrossRef] [PubMed]

97. Schiepers, O.J.G.; Wichers, M.C.; Maes, M. Cytokines and major depression. Prog. Neuro-Psychopharmacol. Biol. Psychiatry 2005, 29, 201-217. [CrossRef] [PubMed]

98. Maze, M.; Cibelli, M.; Grocott, H.P. Taking the Lead in Research into Postoperative Cognitive Dysfunction. Anesthesiology 2008, 108, 1-2. [CrossRef] [PubMed]

99. Xie, G.; Zhang, W.; Chang, Y.; Chu, Q. Relationship between perioperative inflammatory response and postoperative cognitive dysfunction in the elderly. Med. Hypotheses 2009, 73, 402-403. [CrossRef] [PubMed]

100. Zakzanis, K.K.; Mraz, R.; Graham, S.J. An fMRI study of the Trail Making Test. Neuropsychologia 2005, 43, 1878-1886. [CrossRef] [PubMed]

101. González-Scarano, F.; Baltuch, G. Microglia as mediators of inflammatory and degenerative diseases. Annu. Rev. Neurosci. 1999, 22, 219-240. [CrossRef] [PubMed]

102. Gahtan, E.; Overmier, J.B. Inflammatory pathogenesis in Alzheimer's disease: Biological mechanisms and cognitive sequeli. Neurosci. Biobehav. Rev. 1999, 23, 615-633. [CrossRef]

103. O’Brien, R.J.; Wong, P.C. Amyloid precursor protein processing and Alzheimer's disease. Annu. Rev. Neurosci. 2011, 34, 185-204. [CrossRef] [PubMed]

104. Ciallella, J.R.; Ikonomovic, M.D.; Paljug, W.R.; Wilbur, Y.I.; Dixon, C.E.; Kochanek, P.M.; Marion, D.W.; DeKosky, S.T. Changes in Expression of Amyloid Precursor Protein and Interleukin-1 $\beta$ after Experimental Traumatic Brain Injury in Rats. J. Neurotrauma 2002, 19, 1555-1567. [CrossRef] [PubMed]

105. Wang, F.; Wang, Y.; Wu, H.; Lei, L.; Xu, S.; Shen, X.; Guo, X.; Shen, R.; Xia, X.; Liu, Y.; et al. Postoperative Cognitive Dysfunction: Current Developments in Mechanism and Prevention. Med. Sci. Monit. 2014, 20, 1908-1912. [CrossRef] [PubMed]

106. Sanguineti, V.A.; Wild, J.R.; Fain, M.J. Management of Postoperative Complications. Clin. Geriatr. Med. 2014, 30, 261-270. [CrossRef] [PubMed]

107. Wang, Y.; Sands, L.P.; Vaurio, L.; Mullen, E.A.; Leung, J.M. The Effects of Postoperative Pain and Its Management on Postoperative Cognitive Dysfunction. Am. J. Geriatr. Psychiatry 2007, 15, 50-59. [CrossRef] [PubMed]

108. Hudetz, J.A.; Iqbal, Z.; Gandhi, S.D.; Patterson, K.M.; Byrne, A.J.; Hudetz, A.G.; Pagel, P.S.; Warltier, D.C. Ketamine attenuates post-operative cognitive dysfunction after cardiac surgery. Acta Anaesthesiol. Scand. 2009, 53, 864-872. [CrossRef] [PubMed]

109. Fan, L.; Wang, T.-L.; Xu, Y.C.; Ma, Y.H.; Ye, W.G. Minocycline may be useful to prevent/treat postoperative cognitive decline in elderly patients. Med. Hypotheses 2011, 76, 733-736. [CrossRef] [PubMed] 
110. Krause, D.L.; Müller, N. Neuroinflammation, Microglia and Implications for Anti-Inflammatory Treatment in Alzheimer's Disease. Int. J. Alzheimers Dis. 2010, 2010, 732806. [CrossRef] [PubMed]

111. Van Marum, R.J. Update on the use of memantine in Alzheimer's disease. Neuropsychiatr. Dis. Treat. 2009, 5, 237-247. [CrossRef] [PubMed]

112. Rosi, S.; Ramirez-Amaya, V.; Vazdarjanova, A.; Esparza, E.E.; Larkin, P.B.; Fike, J.R.; Wenk, G.L.; Barnes, C.A. Accuracy of hippocampal network activity is disrupted by neuroinflammation: Rescue by memantine. Brain 2009, 132, 2464-2477. [CrossRef] [PubMed]

113. Budni, J.; Feijó, D.P.; Batista-Silva, H.; Garcez, M.L.; Mina, F.; Belletini-Santos, T.; Krasilchik, L.R.; Luz, A.P.; Schiavo, G.L.; Quevedo, J. Lithium and memantine improve spatial memory impairment and neuroinflammation induced by $\beta$-amyloid 1-42 oligomers in rats. Neurobiol. Learn. Mem. 2017, 141, 84-92. [CrossRef] [PubMed]

114. Folch, J.; Busquets, O.; Ettcheto, M.; Sánchez-López, E.; Castro-Torres, R.D.; Verdaguer, E.; Garcia, M.L.; Olloquequi, J.; Casadesús, G.; Beas-Zarate, C.; et al. Memantine for the Treatment of Dementia: A Review on its Current and Future Applications. J. Alzheimers Dis. 2018, 62, 1223-1240. [CrossRef] [PubMed]

115. Ghaffary, S.; Ghaeli, P.; Talasaz, A.H.; Karimi, A.; Noroozian, M.; Salehiomran, A.; Jalali, A. Effect of memantine on post-operative cognitive dysfunction after cardiac surgeries: A randomized clinical trial. DARU J. Pharm. Sci. 2017, 25, 24. [CrossRef] [PubMed]

(C) 2019 by the authors. Licensee MDPI, Basel, Switzerland. This article is an open access article distributed under the terms and conditions of the Creative Commons Attribution (CC BY) license (http:// creativecommons.org/licenses/by/4.0/). 